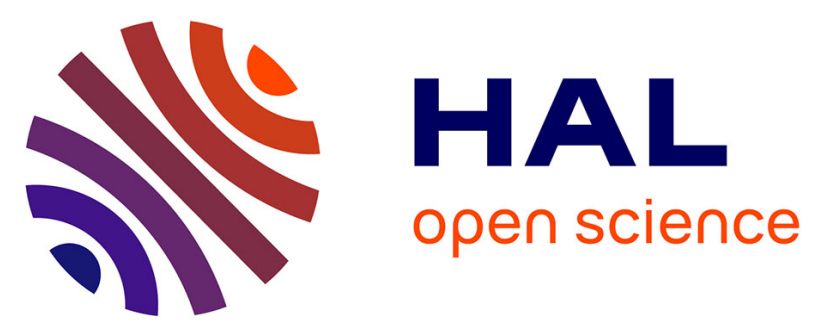

\title{
Sea-ice edge is more important than closer open water access for foraging Adélie penguins: evidence from two colonies
}

Candice Michelot, Akiko Kato, Thierry Raclot, K. Shiomi, Pauline Goulet, Paco Bustamante, Yan Ropert-coudert

\section{To cite this version:}

Candice Michelot, Akiko Kato, Thierry Raclot, K. Shiomi, Pauline Goulet, et al.. Sea-ice edge is more important than closer open water access for foraging Adélie penguins: evidence from two colonies. Marine Ecology Progress Series, 2020, 640, pp.215-230. 10.3354/meps13289 . hal-02553482

\section{HAL Id: hal-02553482 \\ https://hal.science/hal-02553482}

Submitted on 6 May 2020

HAL is a multi-disciplinary open access archive for the deposit and dissemination of scientific research documents, whether they are published or not. The documents may come from teaching and research institutions in France or abroad, or from public or private research centers.
L'archive ouverte pluridisciplinaire HAL, est destinée au dépôt et à la diffusion de documents scientifiques de niveau recherche, publiés ou non, émanant des établissements d'enseignement et de recherche français ou étrangers, des laboratoires publics ou privés. 
Sea-ice edge is more important than closer open water access for foraging Adélie penguins: evidence from two colonies

C. Michelot ${ }^{1, *}$, A. Kato ${ }^{1}$, T. Raclot ${ }^{2}$, K. Shiomi ${ }^{3}$, P. Goulet ${ }^{4}$, P. Bustamante ${ }^{5,6}$, Y. RopertCoudert $^{1}$

${ }^{1}$ Centre d'Etudes Biologiques de Chizé, La Rochelle Université - CNRS, UMR 7372, 79360 Villiers en Bois, France

${ }^{2}$ Institut Pluridisciplinaire Hubert Curien - CNRS, UMR 7178, 67200 Strasbourg, France

${ }^{3}$ National Institute of Polar Research, Tokyo 190-8518, Japan

${ }^{4}$ Sea Mammal Research Unit, University of St Andrews, St Andrews KY16 9XL, UK

${ }^{5}$ Littoral, Environnement et Sociétés, La Rochelle Université - CNRS, UMR 7266, 17000 La Rochelle, France

${ }^{6}$ Institut Universitaire de France (IUF), 1 rue Descartes, 75005 Paris, France

*Corresponding author: candice.michelot@gmail.com 
ABSTRACT: Sentinel species, like Adélie penguins, have been used to assess the impact of environmental changes, and their link with sea ice has received considerable attention. Here, we tested if Adélie penguins from 2 colonies in East Antarctica target the distant sea-ice edge or take advantage of closer open waters that are readily available near their colony. We examined the foraging behaviour of penguins during the incubation trips of females in 2016 and males in 2017, using GPS tracking and diet data in view of daily sea-ice data and bathymetry. In 2016-2017, sea-ice cover was extensive during females' trips but flaw leads and polynyas were close to both study sites. Sea ice receded rapidly during males' trips in 2017-2018. Despite close open water near both colonies in both years, females and males preferentially targeted the continental slope and the sea-ice edge to forage. In addition, there was no difference in the diet of penguins from both colonies: all penguins fed mostly on Antarctic krill and males also foraged on Antarctic silverfish. Our results highlight the importance of the sea-ice edge for penguins, an area where food abundance is predictable. It is likely that resource availability was not sufficient in closer open water areas at such an early stage in the breeding season. The behaviours displayed by the penguins from both colonies were similar, suggesting a common behaviour across colonies in Terre Adélie, although additional sites would be necessary to ascertain this hypothesis.

Keywords: Pygoscelis adeliae; Incubation trip; Sea-ice edge; Colony; Diet; GPS; Stable isotopes 


\section{INTRODUCTION}

The climate is rapidly changing and this has important impacts on the Arctic and Antarctic, which are major regulators of the global climate (Massom et al. 2013, Hobbs et al. 2016). In the last $30 \mathrm{yr}$, the annual sea-ice extent in Antarctica has increased by $1.5 \%$ decade $^{-1}$ in response to atmospheric and oceanic warming (Collins et al. 2013, Comiso et al. 2017). However, according to models, Antarctica will experience a major sea-ice extent loss by the end of the century (Collins et al. 2013, England et al. 2018).

In polar regions, ecosystem dynamics are mostly driven by sea ice (Massom \& Stammerjohn 2010), as sea-ice covered areas play a key role in biogeochemical cycles and primary production and represent highly productive habitats (Nicol et al. 2000, Arrigo \& van Dijken 2003, Massom \& Stammerjohn 2010). More specifically, sea-ice ecosystem dynamics depend on seasonal change in sea-ice growth, extent and retreat. In this system, partially covered open water areas characterized by diffuse sea-ice conditions, called marginal ice zones (MIZ), represent areas of high primary production, as they are the first to be exposed to increasing light penetration in early spring (Massom et al. 1998, Arrigo \& van Dijken 2003). Diatoms, which are at the base of the 'food chain of giants' (Smetacek et al. 2004), develop in those areas and enhance krill and fish presence, which are then consumed by higher trophic level species. As the interface between open water and ice, the MIZ is found at the ice edge, but also at the borders of coastal polynyas and flaw leads. There are various ways of defining these structures; here, we follow the definitions of Massom et al. (1998), Smith \& Barber (2007) and Massom \& Stammerjohn (2010). Polynyas are large areas of open water that form, often recurrently, in the coastal zone and are characterized by persistent fast-ice. Flaw leads are long, linear, ephemeral water accesses that separate the persistent fast-ice from the packice, and are characterized by large drifting ice floes. Finally, the ice edge delimits the 
transition from the pack-ice to open sea and also presents highly productive conditions (Massom et al. 1998, Smith \& Barber 2007, Massom \& Stammerjohn 2010). Despite physical and biogeochemical differences around Antarctica, the MIZ is important for predators' foraging activity around the continent (Karnovsky et al. 2007, Labrousse et al. 2018). The occurrence of polynyas positively influences the presence of emperor penguin Aptenodytes forsteri breeding colonies (Massom et al. 1998) and the size of Adélie penguin Pygoscelis adeliae colonies (Ainley 2002, Arrigo \& van Dijken 2003). In addition, during the winter when the sea-ice cover becomes a physical barrier, partially or totally ice-free areas are used as air-breathing access or as predictable foraging grounds for predators (Karnovsky et al. 2007, Labrousse et al. 2018). In spring and summer, they can also be used as major transiting areas to rapidly reach profitable foraging grounds under extensive sea-ice conditions (Kato et al. 2002, Clarke et al. 2006, Widmann et al. 2015). The dependence of predators on sea-ice conditions makes them particularly suitable as indicators of the state of the ecosystem. Being located in the higher levels of trophic chains, top predators integrate and respond rapidly to changes occurring at lower levels (e.g. emperor penguins, Jenouvrier et al. 2012; Adélie penguins, Cimino et al. 2016; south polar skuas Catharacta maccormicki, Pacoureau et al. 2019). Central place foraging predators that breed on land and commute regularly between the land and the sea to feed during the breeding season (Elliott et al. 2009) are also easily observable. Together with information on dietary regime, the study of their foraging behaviour can inform ecosystem dynamics and resource availability in such a dynamic environment (Frederiksen et al. 2007, Bost et al. 2009).

Among the meso-predators, the Adélie penguin is often referred to as the 'bellwether' of the sea-ice ecosystem (Ainley 2002). This sentinel species is the most abundant seabird species in Antarctica, with more than 3.79 million pairs around the continent (Lynch \& LaRue 2014). Their foraging behaviour and breeding success are closely related to sea-ice conditions 
and dynamics during the winter but also during the summer period, as they time their reproduction to match the peak of food availability (Ainley 2002, Emmerson et al. 2015, Ropert-Coudert et al. 2018). They mainly feed on Antarctic and ice krill (Euphausia superba and E. crystallorophias), and also on Antarctic silverfish Pleuragramma antarctica (Wienecke et al. 2000, Ainley 2002, Cherel 2008). The development and abundance of their main prey are highly dependent on the sea-ice dynamics throughout the winter (Knox 1994, Koubbi et al. 2010, Meyer et al. 2017). During the winter, microalgae and bacteria attach underneath the sea ice where krill come to graze on them and reproduce (Meyer et al. 2017). In spring, the ice breaks and makes krill — and subsequently, fish-available to penguins and other upper predators (Knox 1994, Wienecke et al. 2000). Adélie penguins' optimal growth rate and foraging activity are found under moderate sea-ice cover conditions and often associated with sea-ice concentration around $15-20 \%$, i.e. diffuse sea-ice conditions found in the MIZ (Ainley 2002, Ballard et al. 2010, Barbraud et al. 2015, Le Guen et al. 2018). To examine their dependence on sea ice, the foraging behaviour of Adélie penguins has been studied at distant sites with contrasted sea-ice conditions (Watanuki et al. 1997, 2002) or at a given colony but in years of different sea-ice conditions and/or at different breeding stages (Wienecke et al. 2000, Clarke et al. 2006, Nesti et al. 2010, Erdmann et al. 2011, Le Guen et al. 2018). However, data on Adélie penguin foraging behaviour has, to date, only been obtained from a restricted number of colonies, mostly in relation to the relative ease of access of these sites to researchers.

In 2010, the intrusion of the B09B iceberg in Commonwealth Bay, East Antarctica, led to high fast-ice expansion in that region. Before this event, the Commonwealth Bay area was rarely covered by sea ice (Clark et al. 2015, Wilson et al. 2016). In recent years, episodes of extreme sea-ice extent coupled with rainfall in Terre Adélie (East Antarctica) led to massive breeding failures in the colony of Adélie penguins, as well as other seabirds, on the 
Ile des Pétrels (Barbraud et al. 2015, Ropert-Coudert et al. 2018). The change in the icescape coupled with the occurrence of extreme weather events mean that the region and the resident animal populations are now facing new challenges. Populations on the Ile des Pétrels have been intensively studied over the past years, and the foraging behaviour of Adélie penguins breeding there has received considerable attention (Ropert-Coudert et al. 2001a,b, 2002a,b, 2004, Cottin et al. 2012, Widmann et al. 2015, Le Guen et al. 2018). However, the foraging response to the new icescape situation by colonies located east and west of this well-known colony remains unknown.

In this context, and bearing in mind the potential role of polynyas and/or flaw leads noted above, the goal of our study was to test if Adélie penguins tend to target the distant seaice edge or if they take advantage of closer open water areas to optimize their foraging activity. We tested this on the first incubation trips of Adélie penguins from 2 colonies in East Antarctica: the regularly studied colony of Ile des Pétrels (near Dumont d'Urville French station, Terre Adélie) and that of Cap Bienvenue, $24 \mathrm{~km}$ east of the former (Fig. 1). We expected birds from the 2 colonies to target the MIZ from the closest available open water areas, especially under extensive sea-ice conditions, as seen in other colonies and with other species (Kato et al. 2002, Cottin et al. 2012, Labrousse et al. 2018).

\section{MATERIALS AND METHODS}

\subsection{Study area and foraging data}

During the breeding seasons of 2016 and 2017, Adélie penguin foraging data were collected at 2 locations in East Antarctica: a colony located on the Ile des Pétrels, near the Dumont d'Urville French research station $\left(66.66^{\circ} \mathrm{S}, 140.01^{\circ} \mathrm{E}\right)$, and a colony on Cap Bienvenue $\left(66.72^{\circ} \mathrm{S}, 140.52^{\circ} \mathrm{E}\right)$. These 2 colonies are separated by a stretch of coastline and 
the Astrolabe Glacier with no colonies between them (Fig. 1) and are surrounded by other distant colonies (Barbraud et al. 1999, Lynch \& LaRue 2014). About 15000 and 24100 breeding pairs of Adélie penguins are present in those 2 colonies respectively (C. Barbraud \& K. Delord unpubl. data; counts made in November 2017 and December 2016 respectively) .

In 2016, a total of 16 females from the Ile des Pétrels colony were instrumented with GPS loggers before their first incubation trip, between 19 and 23 November. Three types of GPS devices were used: 11 CatTrack, 4 CatLog (Catnip Technologies), ca. $14 \times 35 \times 70 \mathrm{~mm}$, $30 \mathrm{~g}$ and customized to be waterproof (see Widmann et al. 2015 for details), recording a location every $15 \mathrm{~min}$; and 1 AxyTrek (TechnoSmart), ca. $8 \times 35 \times 70 \mathrm{~mm}, 28 \mathrm{~g}$, recording 1 location $\min ^{-1}$. In addition, on 22 November 2016, 16 females from the Cap Bienvenue colony were equipped with CatTrack GPS loggers (same characteristics as above). For both sites, loggers were attached on the birds' back feathers with marine tape and mastic, and secured with cable-ties (Wilson et al. 1997). Birds were released at their nest. Upon their return from a single trip at sea, equipped penguins were recaptured on their nest to retrieve the loggers, and blood samples $(1-2 \mathrm{ml})$ were collected from the bird's foot vein into a syringe containing heparin to avoid blood clotting.

Similarly, in 2017, a total of 20 males from the Ile des Pétrels colony were instrumented with GPS loggers before their first incubation trip. A total of 10 CatTrack and 10 AxyTrek were deployed between 4 and 8 December. The AxyTreks were set to record locations every $1 \mathrm{~min}$ while the CatTracks were set to record locations every $15 \mathrm{~min}$. On 6 December, 15 males from the Cap Bienvenue colony were instrumented with CatTrack, recording 1 point every $15 \mathrm{~min}$. The same attachment and removal procedures as for the females were used.

On Ile des Pétrels, the nest and partner of the tagged birds were monitored from a distance every $3 \mathrm{~h}$. Upon return of the tagged individual, the date and time were noted and the 
loggers removed. On Cap Bienvenue, we timed a second visit to the colony to coincide with the estimated return date of the tagged bird using the phenology of the Ile des Pétrels colony, as breeders are relatively well synchronized early in the season. In 2016, the second visit took place on 19 December, while in 2017, 3 visits to Cap Bienvenue took place on 25 and 30 December 2017 and 5 January 2018.

\subsection{Environmental data}

Environmental data were extracted for our study area, between $61-68^{\circ} \mathrm{S}$ and 134 $147^{\circ} \mathrm{E}$, and transformed into raster map with the 'raster' package in R v.3.5.1 (Hijmans et al. 2015, R Core Team 2017), with a grid cell resolution of $6.25 \mathrm{~km}$ representing an area covering $516165.9 \mathrm{~km}^{2}$.

We used bathymetric data from the finest available (at that time) resolution GVdem data set (Beaman et al. 2011; NASA, grid cell resolution: $0.001 \times 0.001$ arc-degree), which covers an area of $302476.4 \mathrm{~km}^{2}$ between $63-69^{\circ} \mathrm{S}$ and $138-148^{\circ} \mathrm{E}$, i.e. the majority of the study area used by birds except for the western part. To include the latter, we used the international bathymetric chart of the Southern Ocean (IBCSO) data set (Arndt et al. 2013; grid cell resolution: $500 \mathrm{~m}$, covering the whole Southern Ocean, based on a stereographic projection), averaged on the raster grid of the study area. The bathymetric features were extracted with the 'rasterToContour' function of the 'raster' package in R. The continental shelf was delimited between 0 and $549 \mathrm{~m}$ depth, with the shelf break between 500 and $549 \mathrm{~m}$. The continental slope between 550 and $3500 \mathrm{~m}$ was divided in 3 depth strata. The first stratum, between 550 and $1999 \mathrm{~m}$, is characterized by a complex network of submarine canyons; the second, between 2000 and $2999 \mathrm{~m}$, is characterized by the presence of deep-sea channels; and the third, between 3000 and 3499 m, has a lower gradient than the other strata. 
The abyssal plain was considered at depths greater than $3500 \mathrm{~m}$ (Koubbi et al. 2010, Beaman et al. 2011) (see Fig. 2).

Daily sea-ice concentration data (Advanced Microwave Scanning Radiometer, AMSR-2, grid cell resolution of $6.25 \times 6.25 \mathrm{~km}$ ) were downloaded from the website of the University of Bremen (https://seaice.uni-bremen.de/data/amsr2/asi_daygrid_swath/s62502 from the date the first bird was equipped to the date of last logger recovery, for each season.

Open water features were extracted from the daily sea-ice concentration following the same procedure as for bathymetric features. The sea-ice edge was defined as the last $15 \%$ of sea-ice concentration cells before the open sea (Stammerjohn \& Smith 1997, Massom \& Stammerjohn 2010). Polynyas were defined as any cells of open water that were totally surrounded by sea ice $(>15 \%)$. Three recurrently observed polynyas were detected: the Dumont d'Urville polynya in the vicinity of the Ile des Pétrels (around the centroid located $66.1^{\circ} \mathrm{S}, 139.6^{\circ} \mathrm{E}$, slightly west from the colony), the Commonwealth Bay polynya (around the centroid located $66.2^{\circ} \mathrm{S}, 142^{\circ} \mathrm{E}$, east of Cap Bienvenue) and the Mertz polynya (around the centroid located $66.6^{\circ} \mathrm{S}, 147.2^{\circ} \mathrm{E}$ and opening around the Mertz glacier). Finally, flaw leads with a surface equivalent or larger than the smallest polynya recorded during the season were extracted with $50 \%$ of sea-ice concentration to account for larger portion of ice-free areas (Videos S1 \& S2).

Each cell was assigned a binary value: 0 if the cell corresponded to an open water fraction (flaw lead/polynya or open sea beyond the ice-edge) or 1 otherwise. To ascertain that birds were genuinely on sea ice with limited access to open water, and to account for the MIZ around each open water feature, we attributed a value of 0 to cells located in a $12.5 \mathrm{~km}$ buffer ( 2 rows of cells) around the contour of each open water feature. 
We calculated the nearest distance between each grid cell centroid and each colony using the 'gridDistance' function from the 'raster' package. We also calculated the nearest distance between each colony and each bathymetric and open water feature, using the 'dist2Line' function from the 'geosphere' package.

\subsection{GPS data cleaning and processing}

GPS tracks were processed using R v.3.5.1 (R Core Team 2017). Duplicate points corresponding to artefacts of recording ( 2 points recorded at the exact same location) and an excess of points at the colony before the departure and after the return of penguins were removed. Outlier points (e.g. locations with impossible date-time, or points with a Northern Hemisphere latitude), considered unrealistic, were also removed. Incomplete tracks from birds from Cap Bienvenue colony were removed from the analysis. For incomplete tracks from the Ile des Pétrels birds, a point at the colony, with the date and time of the bird's return noted from the regular visual checks of the nests, was virtually added. Using this approach, tracks for which more than $60 \%$ of the total trip duration was recorded were kept and completed with a straight line on their inward journey, between the last location recorded and the point added at their returning date-time to the colony. Doing so, the approximate distance travelled and potential habitat crossed during the birds' inward journey were taken into account in the analyses. GPS tracks were then resampled with a regular time step of 30 min, using the 'redisltraj' function of the R package 'adehabitatLT' (Calenge 2015), to have regular steps between locations and to avoid too many location interpolations, as some gaps between locations can occur during birds' dives. A total of 10 tracks in each colony were kept for the females' first incubation trips in 2016-2017 (see Table 1), and 14 and 10 tracks for males from Cap Bienvenue and Ile des Pétrels respectively in 2017-2018. Among the tracks kept, only 4 female tracks and 1 male track were incomplete and kept in the analysis. The 
missing part of their trips (which was interpolated) represented between 0.2 and $9.6 \%$ of the females' trip durations, and $20 \%$ of the male's trip.

The following parameters were defined for each bird: total distance travelled $(\mathrm{km})$, total trip duration (h) and maximal distance to the colony $(\mathrm{km})$. Heading of birds $24 \mathrm{~h}$ after their departure was calculated, relative to their colony and relative to the closest open water point (polynya, ice-edge, open sea or flaw leads), on the day of their departure, to assess if birds were targeting the nearest open water area available. The residence time, i.e. the number of locations in each cell per day, was used as a proxy for searching and diving activity (Peron et al. 2012, Warwick-Evans et al. 2015) and was related to environmental variables in the given cell.

\subsection{Trophic niche}

Analyses of the stable isotopes of nitrogen $\left(\delta^{15} \mathrm{~N}\right)$ and carbon $\left(\delta^{13} \mathrm{C}\right)$ were used to estimate the trophic niche of Adélie penguins and the position of the prey they ingested. Immediately after collection, the blood was centrifuged at $5000 \mathrm{rpm}$ for $7 \mathrm{~min}$ to separate red blood cells from plasma that were both stored at $-20^{\circ} \mathrm{C}$. Plasma, with a turnover ranging from days to weeks, was used for examining diet during the incubation trip (Hobson \& Clark 1992, Beaulieu et al. 2010, Barquete et al. 2013). Plasma samples were first lyophilized for 48 h, powdered, weighed and then lipid-extracted. Indeed, as lipids are highly depleted in ${ }^{13} \mathrm{C}$ relative to other tissue components (DeNiro \& Epstein 1977), they were removed using a chloroform-methanol solution $(2: 1 \mathrm{~V}: \mathrm{V}$ derived from the Folch's procedure), at the LIttoral ENvironnement et Sociétés (LIENSs, La Rochelle, France). The samples were then encapsulated into tin capsules $(0.2-0.4 \mathrm{mg})$ for stable isotope analysis trough isotope-ratio mass spectrometry. Isotopic analyses were performed with a Thermo Scientific Delta V Advantage mass spectrometer coupled to a Thermo Scientific Flash EA1112 elemental 
analyser. Results are presented in the usual $\delta$ notation relative to the deviation from standards (Vienna PeeDee Belemnite for $\delta^{13} \mathrm{C}$ and atmospheric $\mathrm{N}_{2}$ for $\delta^{15} \mathrm{~N}$ ), in parts per thousand (\%o). Replicate measurements of internal laboratory standards (acetanilide and peptone) indicated measurement errors $<0.15 \%$ for both $\delta^{13} \mathrm{C}$ and $\delta^{15} \mathrm{~N}$ values. The standard ellipse area corrected for small sample size (SEAC), an ellipse representing the probability of containing $40 \%$ of the data, and the Bayesian standard ellipses areas (SEAB) ('SIBER' package in R; Jackson et al. 2011) were used to estimate the isotopic niches used by birds from the 2 colonies each year, with $2 \times 10^{5}$ replicates for quantifying the uncertainty and allowing robustness in our statistical analysis. We calculated the SEA $A_{C}$ and the area of overlap between the 40 and $95 \%$ isotopic niches from the $\mathrm{SEA}_{\mathrm{B}}$ using the maximum likelihood ellipses for the 2 groups.

\subsection{Statistical analysis}

The normality of trip duration, distance travelled, maximum distance, heading and isotopic ratios were tested with Shapiro-Wilks test. The equality of the variance was tested using Fisher's test. Finally, differences in the aforementioned parameters between colonies were tested using Student's $t$-test if normality and homogeneity of variances were respected, or Mann-Whitney test if not. Results are presented as means \pm SD.

Two generalised linear mixed-effect models with a negative binomial distribution were built for each season, to compare the effects of both open water and bathymetric features on the residence time of birds. An interaction term was added to compare the effect of each feature on residence time according to the colony of origin. A random effect was added to the model to take into account the individual effect in the variability of the response variable. Models were built with the 'glmer.nb' function of the 'lme4' package in R (Bates et al. 2015). Statistical significance was defined at $\mathrm{p} \leq 0.05$. ANOVA was performed for each model to 
test the significance of the relationship among variables, with the 'Anova' function from the 'car' package. A Wald test of Type II was applied. Then, a post hoc test was performed to compare 2 by 2 the difference of the effect of features on bird residence time within each colony. It also allowed us to determine the significant difference between the 2 colonies for each feature. The post hoc tests were performed using the 'emmeans' function from the $\mathrm{R}$ package 'emmeans' (Lenth 2018).

Note that females and males were monitored in 2 different years and at 2 different times of the season (beginning of incubation for females in 2016, end of incubation for males in 2017), which precluded us from conducting a sex comparison of foraging parameters.

\section{RESULTS}

\subsection{Sea-ice conditions}

In 2016, the sea-ice extent was high during the females' first incubation trip (20 November to 22 December), extending on average $177.3 \pm 36.2$ and $176.1 \pm 33.0 \mathrm{~km}$ from the Ile des Pétrels and Cap Bienvenue colonies respectively. The large polynya of the Commonwealth Bay $\left(1794.0 \pm 1006.0 \mathrm{~km}^{2}\right)$ was $63.9 \pm 5.4 \mathrm{~km}$ from the Cap Bienvenue colony and, like the Mertz polynya, remained present during the time the females were at sea. In contrast, the Dumont d'Urville polynya did not open; the closest open water to the Ile des Pétrels—Commonwealth Bay polynya—was $80.9 \pm 3.9 \mathrm{~km}$ away. Females from both sites had access to flaw leads opening along the shelf edge during their trips (Videos S1, S3 \& S4).

In 2017, sea-ice conditions varied greatly over the incubation period of the males (429 December): large open water areas were already available at the start of the male incubation trip period, followed by a marked sea-ice retreat during which polynyas alternated 
with open sea. Sea-ice extent was on average $127.8 \pm 89.0 \mathrm{~km}$ from Cap Bienvenue and 131.9 $\pm 83.6 \mathrm{~km}$ from the Ile des Pétrels over the study period. When it appeared $(1 \mathrm{~d}$ only during the period), the $1057.2 \mathrm{~km}^{2}$ Commonwealth Bay polynya was $91.4 \mathrm{~km}$ east of Ile des Pétrels, and $81.2 \mathrm{~km}$ east of Cap Bienvenue. During the $15 \mathrm{~d}$ it was opened, the Dumont d'Urville polynya was located on average $52.5 \pm 20.4 \mathrm{~km}$ west of Cap Bienvenue and $39.4 \pm 14.7 \mathrm{~km}$ of the Ile des Pétrels. Its area ranged from 577.2 to $4460.3 \mathrm{~km}^{2}$ during this period, with an averaged area of $2841.6 \pm 1136.9 \mathrm{~km}^{2}$ (Videos S2, S5 \& S6).

\subsection{Adélie penguin foraging behaviour}

Females left the Ile des Pétrels between 20-24 November 2016 and returned between 9-22 December 2016 (Figs. 2A, Video S3). Females left Cap Bienvenue between 22-25 November 2016 and returned between 7-8 December 2016 (Figs. 2B, Video S4). In total, 11 functional GPS units were recovered in each colony, but only 20 tracks with $60 \%$ or more of the trip covered (10 in each colony) were kept for analyses. Males left the Ile des Pétrels between 4-8 December 2017 and returned between 18-24 December 2017 (Figs. 2C, Video S5). Males left Cap Bienvenue on 6-7 December 2017 and returned between 20-29 December 2017 (Figs. 2D, Video S6).

There were no significant differences in trip duration, total distance covered during the trip and maximum distance to the colony between the 2 colonies for both females and males (Table 1). However, females from Ile des Pétrels headed north-west in their first day at sea ($\left.25.20 \pm 5.71^{\circ}\right)$, whereas females from Cap Bienvenue headed significantly $(\mathrm{p}=0.015)$ more north $\left(7.17 \pm 11.98^{\circ}\right)$. Surprisingly, females from both sites did not head towards the nearest open water (Commonwealth Bay polynya in the north-east) or the nearest ice edge (also north-east) (Fig. 3A,B), except for one female from Cap Bienvenue that went in the direction 
of the closest edge point. Only 2 females from Cap Bienvenue crossed the Commonwealth Bay polynya before continuing their way to the ice edge.

In 2017, males from the Ile des Pétrels headed towards the north-west $(-18.08 \pm$ $\left.6.66^{\circ}\right)$ on their first day at sea, while males from Cap Bienvenue headed north-east $(32.01 \pm$ $\left.19.45^{\circ}\right)$; this was significantly different between the 2 colonies $(\mathrm{p}<0.001)$ (Fig. 3C,D). By doing so, the Ile des Pétrels males travelled in the direction of the closest open water point (the sea-ice edge). The date of 8 December was an exception, however: the Dumont d'Urville polynya appeared and was at that point the closest open water area from the colony, compared with the sea-ice edge which had moved north-east. Yet males departing on 8 December continued to head towards the north-west (Fig. 3C). All Cap Bienvenue males that started their trip on 6 December headed towards the north-east but the closest open water point was the sea-ice edge located north-west of the colony. On the next day, the sea-ice edge had moved, and the closest open water point was then located east of the colony (Fig. 3D). As males did not change their main direction of travel, they headed closer to the nearest open water area on that occasion, except for one male that went north-west, where the closest open water point had been located the day before (indicated on Fig. 3D). Before reaching the furthest point away from their respective colony, 6 males from the Ile des Pétrels and 2 from Cap Bienvenue crossed the Dumont d'Urville polynya. Although birds from a given colony did not leave on the same day, penguins of both sexes followed approximately similar directions, except for one male from Cap Bienvenue.

In 2016, females from both colonies spent similar residence times in each open water feature (Fig. 4A) and in each bathymetric feature (Fig. 4B). Within colonies, the Ile des Pétrels females had the lowest residence time in the Commonwealth Bay polynya, compared to the sea ice or at the ice edge (Fig. 4A, Table 2), and they favoured the deep regions of the continental slope between 3000 and $3500 \mathrm{~m}$ and the abyssal plain (Fig. 4B, Table 3). The 
residence time of Cap Bienvenue females was higher at the sea-ice edge and in the open sea than in any other open water features (Table 2). They also spent more time in the abyssal plain and the slope between 3000 and $3500 \mathrm{~m}$ and, to a lesser extent, the slope between 2000 and $2500 \mathrm{~m}$ (Table 3).

In 2017, the males from the Ile des Pétrels had a significantly higher residence time on sea ice $(p=0.036)$ and significantly lower residence time in open sea than males from Cap Bienvenue (Fig. 4C) but, like females, males from both colonies favoured the deep regions of the continental slope between 3000 and $3500 \mathrm{~m}$ and the abyssal plain (Fig. 4D). There was no difference in residence time between colonies for the other open water and bathymetric features (note that no bird from Cap Bienvenue used flaw leads). Within colonies, the Ile des Pétrels males had a significantly higher residence times at the sea-ice edge or on sea ice than in the open sea and the Dumont d'Urville polynya (Fig. 4C, Table 4), and less time at the continental shelf and the slope between 550 and $2000 \mathrm{~m}$, with a clear preference for the abyssal plain (Fig. 4D, Table 5). Cap Bienvenue males spent a significantly higher residence time at the ice edge and in open water than on sea ice or in the Dumont d'Urville polynya (Fig. 4C, Table 4), and also significantly higher residence time in the bathymetry zones deeper than $2000 \mathrm{~m}$ (Fig. 4D, Table 5). In both colonies, males did not show any significant preference for the Commonwealth Bay and Dumont d'Urville polynyas, which were the least visited (Fig. 4C).

\subsection{Trophic niche}

No significant differences were detected between colonies with respect to carbon and nitrogen isotopic ratios, except for Cap Bienvenue males having significantly higher $\delta^{13} \mathrm{C}$ values than males from the Ile des Pétrels (Fig. 5, Table A1 in the Appendix). In 2016, SEA values were 0.42 and $0.48 \%{ }^{2}\left(\mathrm{SEA}=0.37\right.$ and $0.43 \%{ }^{2}$ respectively) for females from Cap 
Bienvenue and Ile des Pétrels respectively. In 2017, values of SEA $\mathrm{s}_{\mathrm{c}}$ were 0.81 and $0.33 \%{ }^{2}$ $\left(\mathrm{SEA}=0.74\right.$ and $\left.0.30 \%{ }^{2}\right)$ for males from Cap Bienvenue and Ile des Pétrels respectively. For both sexes, both the $\mathrm{SEA}_{\mathrm{c}}$ (containing $40 \%$ of the data) of the 2 colonies or the $\mathrm{SEA}_{\mathrm{B}}$ (containing 95\% of the data) overlapped (Fig. 5): the female $\mathrm{SEA}_{c}$ and $\mathrm{SEA}_{\mathrm{B}}$ overlap areas represented 22 and $54 \%$ of the total area respectively; male $\mathrm{SEA}_{c}$ and $\mathrm{SEA}_{\mathrm{B}}$ overlap areas represented 8 and $30 \%$ of the total area respectively. The Ile des Pétrels isotopic niche was greater than that of Cap Bienvenue for females in 2016 and the reverse for males in 2017. The $\delta^{15} \mathrm{~N}$ values of female and male Adélie penguins were between that of the silverfish Pleuragramma antarctica $(10.6 \pm 0.3 \%$, according to Cherel 2008) and that of the Antarctic and ice krill (Euphausia superba, $5.3 \pm 0.5 \%$ and E. crystallorophias, $6.8 \pm 0.7 \%$ o respectively; Cherel 2008).

\section{DISCUSSION}

The foraging behaviour of female and male Adélie penguins from the Cap Bienvenue colony was monitored during the incubation period for the first time. The sea-ice habitat use and foraging activity of these birds were similar overall to that of birds from the well-studied Ile des Pétrels colony, $24 \mathrm{~km}$ away. Unexpectedly, Adélie penguins from both colonies did not target the closest available access to open water or zones with diffuse ice conditions when accessible. Instead, they headed to the distant ice edge and the continental slope regardless of the sea-ice extent.

Adélie penguins are central-place foragers, commuting trips between colonies and foraging habitats during their breeding season (Ainley 2002). The inherent prediction of the central place foraging theory is the occurrence of Storer-Ashmole's halo: central-place foragers tend to forage preferentially in close and suitable areas, leading to prey depletion 
around the breeding colony (Elliott et al. 2009). As such, we expected Adélie penguins to head towards the closest open water area border, where diffuse sea-ice conditions would allow them to dive and forage on abundant resources. Yet penguins did not target the polynyas that are present recurrently in the area or the leads which were opened during their trips, for food provisioning early in the season, nor did they specifically head towards them as transiting areas to reach the ice edge.

Note that because of the $15 \%$ concentration contour definition, the feature defined as 'sea ice' includes solid pack-ice, but also part of MIZ conditions which can extend farther than the $12.5 \mathrm{~km}$ buffer we applied around each open water area. Similarly, open sea or open water features (polynyas, flaw leads or sea-ice edge), i.e. concentration between 0 and $15 \%$ and the $12.5 \mathrm{~km}$ buffer, can also include diffuse MIZs (Massom \& Stammerjohn 2010). Nonetheless, the icescape was very dynamic from one day to another, and it is thus difficult to evaluate how much the penguins anticipated changes occurring in their environment to find the most suitable areas at a given time.

During the late incubation period of 2017, polynyas and flaw leads often merged into open water, and this naturally explains why we noted few visits by males into those features. Some males briefly visited polynyas on their way to the slope (2 males from Cap Bienvenue and 6 from Ile des Pétrels), but did not specifically head towards those features when departing from the colony, as polynyas were mostly merged into open water, and the ice edge was the closest open water area. In contrast, in 2016 the Commonwealth Bay polynya remained open over the whole early incubation period, when sea-ice extent is often greater and more persistent than during the late incubation period. However, neither females from Cap Bienvenue nor the Ile des Pétrels headed to the nearest open water feature at the beginning of their trip. Only a small number of birds visited the polynyas while transiting to the sea-ice edge on their outward journeys ( 2 females from Cap Bienvenue in 2016 only), but 
they apparently did not spend time searching for food, as the low residence time suggests (although additional data would be needed to accurately infer the birds' behavioural state, such as hunting or resting). In fact, birds seemed to leave the colony following a fixed direction, independently of the icescape around the colony or departure date. This suggests a 'group effect', where birds may follow the specific direction taken by other birds leaving the colony before them, as seen in other seabird species (Weimerskirch et al. 2010, Traisnel \& Pichegru 2019). In addition, primary production was highest in the diffuse ice located at the border of both the smaller ephemeral flaw leads and the larger persistent polynyas, resulting in limited availability of profitable areas for predators (Massom et al. 1998, Arrigo \& van Dijken 2003, Labrousse et al. 2018). During the winter, when the sea-ice extent is high, predators such as elephant seals Mirounga leonine and emperor penguins take advantage of open water accesses like polynyas and leads to feed (Kirkwood \& Robertson 1997, McMahon et al. 2002, Labrousse et al. 2018). As such, inter-specific competition can subsequently occur in those available but restricted foraging areas, leading to avoidance of those features by penguins. Although flaw leads can represent important transiting or foraging grounds, their ephemeral occurrence means they may not be targeted by predators due to their low predictability.

The extensive use of polynyas and leads by top predators during winter and early spring may substantially reduce prey availability in such restricted foraging grounds. At the beginning of the breeding season, when Adélie penguins go to sea for their first incubation trip, resources at the polynyas and leads MIZ may be nearly or completely exhausted. The primary production bloom generally occurs later in the season, at the beginning of the chickrearing period. When the incubation period starts, the development of phytoplankton, and consequently the concentration of prey such as krill or fish, may be low and therefore insufficient to sustain penguins (Knox 1994, Massom et al. 1998, Beaulieu et al. 2010). Thus, 
penguins may forage near the polynyas only later in the season, during the critical chickrearing period. Indeed, during this part of their breeding cycle, Adélie penguins need to commute regularly to the nest to provision the chicks. As coastal polynyas are known to be highly dynamic and productive areas during the summer (Massom et al. 1998, Arrigo \& van Dijken 2003), Adélie penguins can use them as important foraging grounds for efficiently provisioning their chicks, especially when the sea-ice extent is high (Ainley 2002, Arrigo \& van Dijken 2003, Clarke et al. 2006, Widmann et al. 2015). This idea finds support in the fact that most penguin colonies are located near coastal polynyas (Massom et al. 1998, Ainley 2002, Arrigo \& van Dijken 2003, Ainley et al. 2016).

Incubating Adélie penguins from Lützow-Holm Bay (Kato et al. 2002) and Béchervaise Island (Clarke et al. 2006), 2 other colonies of East Antarctica, also targeted the ice edge but headed straight to the polynya as a way to travel faster to the ice edge, as suggested by the start of diving activity and time elapsed in the trips in the former study, and by analysis of satellite tracking in the latter. Further studies coupling productivity around the polynya during the whole breeding season, associated with Adélie penguins' habitat selection for foraging activity during the chick-rearing period could be useful to assess of the importance of the polynya during that critical stage.

During the incubation, penguins must replenish their body reserves and preferentially head to the distant sea-ice edge, where prey concentration may be more predictable. The ice edge coincides with the continental slope and is a food-enriched area, where primary production first occurs between spring and summer (Knox 1994, Massom et al. 1998, Nicol et al. 2000). It represents an area of predictable food availability and abundance for penguins: the upwelling along the slope allows nutrients to be brought near the surface layer and, coupled with light, benefits the development of plankton (Wienecke et al. 2000, Ainley 2002, Koubbi et al. 2010). Following the fast during pre-laying and egg production for females and 
the incubation fast of males, birds may decide to head directly to zones where they anticipate prey to be available, as is seen in other (even tropical) seabird species (Weimerskirch et al. 2007).

The sea-ice edge and the slope correspond to the habitat range of Antarctic krill, one of the main prey of Adélie penguins, whereas Antarctic silverfish are generally found in more coastal waters where they feed on ice krill (Cherel 2008, Koubbi et al. 2010, 2011). Taking into account the $\delta^{13} \mathrm{C}$ gradient between inshore and offshore Antarctic waters (Cherel 2008, Beaulieu et al. 2010), the carbon isotopic ratios of Adélie penguin in our study suggest that females forage in more oceanic waters, as do males from the Ile des Pétrels, whereas Cap Bienvenue males forage in more neritic waters. However, our $\delta^{13} \mathrm{C}$ values encompass a small range and do not highlight high variations in the habitat of Adélie penguins' foraging activity. Our nitrogen isotopic ratios were higher than the ca. $9 \%{ }^{15} \mathrm{~N}$ measured in adult whole blood samples and the $8.4-8.7 \% \delta^{15} \mathrm{~N}$ in the red blood cells of incubating males (Cherel 2008, Cottin et al. 2012). They also were only slightly lower than the isotopic ratio of Adélie penguin chicks of $10.2 \pm 0.8 \%$ (whole blood analysis; Cherel 2008). Our samples consisted of delipidated plasma, for which $\delta^{15} \mathrm{~N}$ values are about $0.8 \%$ higher than in the red blood cells (but not $\delta^{13} \mathrm{C}$ ), as shown in king Aptenodytes patagonicus and gentoo penguins Pygoscelis papua (Xavier et al. 2017, Cherel et al. 2018). With this in mind, the difference in $\delta^{15} \mathrm{~N}$ values between krill and Adélie penguins in our results corresponds to the natural enrichment factor of about 3.4\% between trophic levels (Post 2002), suggesting that these penguins were feeding principally on Antarctic krill, with males probably feeding on a small proportion of Antarctic silverfish and ice krill leading to an increase in their $\delta^{15} \mathrm{~N}$ values. The results for ecological niche are thus consistent with the Adélie penguins' main prey habitats: penguins fed on lower trophic level species in oceanic waters (lower $\delta^{15} \mathrm{~N}$ and $\delta^{13} \mathrm{C}$ ) and on higher trophic level species in more coastal waters (higher $\delta^{15} \mathrm{~N}$ and $\delta^{13} \mathrm{C}$ ). The persistent ice edge 
near the slope may have favoured the development of the trophic food web in 2016, with high concentrations of Antarctic krill. Females heading to the ice edge located near the slope may have benefited from a high concentration of Antarctic krill in this area. In 2017, the greater sea-ice retreat meant that incubating males had access to a large array of possibilities, including Antarctic krill in the ice edge and continental slope waters but also ice krill and Antarctic silverfish in more neritic waters. Although Adélie penguins favoured the ice edge and open, deep water on the continental slopes, they also spent some time in flaw leads located on the continental shelf, where they may have found other prey such as Antarctic silverfish. Isotopic niches from females from both colonies overlapped, and despite significant difference in $\delta^{13} \mathrm{C}$ values, males from both colonies shared a similar isotopic niche. The low variation in $\delta^{15} \mathrm{~N}$ values highlighted the low diversity in prey consumed at both sites. Moreover, our results are consistent with other studies revealing the intermediate generalist foraging strategy of Adélie penguins, where they feed predominantly on krill during the incubation period but also on fish during the chick-rearing period, both in East Antarctica (Wienecke et al. 2000, Cottin et al. 2012), and the Peninsula (Herman et al. 2017).

The Commission for the Conservation of Antarctic Marine Living Resources (CCAMLR) selected the Adélie penguin as a sentinel species in Antarctica to assess ecosystem variation, and through their krill consumption, to manage krill fisheries (Southwell et al. 2017). Several well-studied colonies are thus used as outposts around the Antarctic but often little is known of the situation in neighbouring colonies, apart from occasional direct or satellite counts (Fretwell \& Trathan 2009, Lynch \& LaRue 2014). For instance, the Ile des Pétrels Adélie penguin colony was recently affected by 2 massive breeding failures (Barbraud et al. 2015, Ropert-Coudert et al. 2018) but there is no information on what happened $24 \mathrm{~km}$ away in the Adélie penguin colony at Cap Bienvenue. Was the breeding success equally affected in Cap Bienvenue? Did the birds there adjust their foraging activity to respond to the 
extensive sea ice differently? Here, our data suggest that foraging activity is consistent across these 2 colonies, at least during the incubation phase. The isotopic niche shared by both colonies and the low variation in prey diversity, in accordance with other studies, highlights the importance of their critical foraging habitat, i.e. diffuse sea-ice zones offering abundant resources such as Antarctic krill but also access to Antarctic silverfish and ice krill.

This is of course only a first attempt at examining consistency across colonies of the Terre Adélie region. In a context where it is logistically difficult to extend long-term monitoring studies on the foraging and demographic activities of species across several remote sites, our results highlight similar foraging behaviour in 2 colonies and suggest that one colony could be used for describing others nearby. While we cannot extrapolate further, this gives some evidence to suggest common measures of conservation that the CCAMLR could put forward in the region to protect the different Adélie penguin colonies and their habitats.

Acknowledgements. This study was approved by the ethics committee of the French Polar Institute Paul Emile Victor (IPEV). We are grateful for all financial and logistic support: the IPEV (program 1091, resp. Y.R.C. \& T.R.), the WWF-UK through R. Downie, the Zone Atelier Antarctique et Subantarctique - LTER France of the CNRS, the Terre Australes et Antarctiques Françaises (TAAF). This study is a contribution to the program SENSEI funded by the BNP Paribas Foundation. We thank M. Brault-Favrou and G. Guillou from LIENSs for stable isotope analysis help and measurements. The IUF (Institut Universitaire de France) is acknowledged for its support to P.B. as a Senior Member. We also thank 2 reviewers for their help in improving an earlier version of the manuscript. 


\section{LITERATURE CITED}

Ainley DG (2002) The Adélie Penguin: Bellwether of Climate Change. Columbia University Press.

Ainley D, Woehler EJ, Lescroël A (2016) Birds and Antarctic sea ice, in: Thomas DN (Ed.), Sea Ice. John Wiley \& Sons, Ltd, Chichester, UK, pp. 570-582.

Arndt JE, Schenke HW, Jakobsson M, Nitsche FO, Buys G, Goleby B, Rebesco M, Bohoyo F, Hong J, Black J, Greku R, Udintsev G, Barrios F, Reynoso-Peralta W, Taisei M, Wigley R (2013) The International Bathymetric Chart of the Southern Ocean (IBCSO) Version 1.0-A new bathymetric compilation covering circum-Antarctic waters. Geophys Res Lett 40(12):3111-3117.

Arrigo KR, van Dijken GL (2003) Phytoplankton dynamics within 37 Antarctic coastal polynya systems. J Geophys Res Oceans 108(C8).

Ballard G, Dugger KM, Nur N, Ainley DG (2010) Foraging strategies of Adélie penguins: adjusting body condition to cope with environmental variability. Mar Ecol Prog Ser 405:287-302.

Barbraud C, Delord K, Micol T, Jouventin P (1999) First census of breeding seabirds between Cap Bienvenue (Terre Adélie) and Moyes Islands (King George V Land), Antarctica: new records for Antarctic seabird populations. Polar Biol 21:146-150.

Barbraud C, Delord K, Weimerskirch H (2015) Extreme ecological response of a seabird community to unprecedented sea ice cover. R. Soc. Open Sci 2(5):140456.

Barquete V, Strauss V, Ryan PG (2013) Stable isotope turnover in blood and claws: A case study in captive African Penguins. J Exp Mar Biol Ecol 448:121-127. 
Bates D, Maechler M, Bolker B, Walker S, Christensen RHB, Singmann H, Dai B, Grothendieck G, Green P (2015) Package 'Ime4: Linear mixed-effects models using Eigen and S4'. Available through the Comprehensive R Archive Network.

Beaman RJ, O’Brien PE, Post AL, De Santis L (2011) A new high-resolution bathymetry model for the Terre Adélie and George V continental margin, East Antarctica. Antarct Sci 23(1):95-103.

Beaulieu M, Dervaux A, Thierry AM, Lazin D, Le Maho Y, Ropert-Coudert Y, Spée M, Raclot T, Ancel A (2010) When sea-ice clock is ahead of Adélie penguins' clock. Funct Ecol 24(1):93-102.

Bost CA, Cotté C, Bailleul F, Cherel Y, Charrassin JB, Guinet C, Ainley DG, Weimerskirch $\mathrm{H}$ (2009) The importance of oceanographic fronts to marine birds and mammals of the southern oceans. J Mar Syst 78(3):363-376.

Calenge C (2015) Analysis of Animal Movements in R: the adehabitatLT Package. R Package version n 0.3, 20.

Cherel Y (2008) Isotopic niches of emperor and Adélie penguins in Adélie Land, Antarctica. Mar Biol 154(5):813-821.

Cherel Y, Parenteau C, Bustamante P, Bost CA (2018) Stable isotopes document the winter foraging ecology of king penguins and highlight connectivity between subantarctic and Antarctic ecosystems. Ecol Evol 8(5):2752-2765.

Cimino MA, Lynch HJ, Saba VS, Oliver MJ (2016) Projected asymmetric response of Adélie penguins to Antarctic climate change. Sci Rep 6:28785.

Clark GF, Marzinelli EM, Fogwill CJ, Turney CSM, Johnston EL (2015) Effects of sea-ice cover on marine benthic communities: a natural experiment in Commonwealth Bay, East Antarctica. Polar Biol 38(3):1213-1222. 
Clarke J, Emmerson L, Otahal P (2006) Environmental conditions and life history constraints determine foraging range in breeding Adélie penguins. Mar Ecol Prog Ser 310:247-261.

Collins M, Knutti R, Arblaster J, Dufresne JL, Fichefet T, Friedlingstein P, Gao X, Gutowski WJ, Johns T, Krinner G, Shongwe M, Tebaldi C, Weaver AJ, Wehner M (2013) Longterm Climate Change: Projections, Commitments and Irreversibility, in: Stocker TF, Qin D, Plattner GK, Tignor M, Allen SK, Boschung J, Nauels A, Xia Y, Bex V, Midgley PM (Eds), Climate Change 2013: The Physical Science Basis. Contribution of Working Group I to the Fifth Assessment Report of the Intergovernmental Panel on Climate Change. Cambridge, United Kingdom and New York, NY, USA, pp. 10291136.

Comiso JC, Gersten RA, Stock LV, Turner J, Perez GJ, Cho K (2017) Positive Trend in the Antarctic Sea Ice Cover and Associated Changes in Surface Temperature. J Clim 30(6):2251-2267.

Cottin M, Raymond B, Kato A, Amélineau F, Le Maho Y, Raclot T, Galton-Fenzi B, Meijers A, Ropert-Coudert Y (2012) Foraging strategies of male Adélie penguins during their first incubation trip in relation to environmental conditions. Mar Biol 159(8):18431852.

DeNiro MJ, Epstein S (1977) Mechanism of carbon isotope fractionation associated with lipid synthesis. Science 197(4300):261-263.

Elliott KH, Woo KJ, Gaston AJ, Benvenuti S, Dall'Antonia L, Davoren GK (2009) Centralplace Foraging in an Arctic Seabird Provides Evidence for Storer-Ashmole's Halo. The Auk 126(3):613-625.

Emmerson L, Southwell C, Clarke J, Tierney M, Kerry K (2015) Adélie penguin response parameters signal reduced prey accessibility: implications for predator-prey response curves. Mar Biol 162(6):1187-1200. 
England M, Polvani L, Sun L (2018) Contrasting the Antarctic and Arctic Atmospheric Responses to Projected Sea Ice Loss in the Late Twenty-First Century. J Clim 31(16):6353-6370.

Erdmann ES, Ribic CA, Patterson-Fraser DL, Fraser WR (2011) Characterization of winter foraging locations of Adélie penguins along the Western Antarctic Peninsula, 20012002. Deep Sea Res Part II Top Stud Oceanogr 58(13-16):1710-1718.

Frederiksen M, Mavor R, Wanless S (2007) Seabirds as environmental indicators: the advantages of combining data sets. Mar Ecol Prog Ser 352:205-211.

Fretwell PT, Trathan PN (2009) Penguins from space: faecal stains reveal the location of emperor penguin colonies. Glob Ecol Biogeogr 18(5):543-552.

Herman RW, Valls FCL, Hart T, Petry MV, Trivelpiece WZ, Polito MJ (2017) Seasonal consistency and individual variation in foraging strategies differ among and within Pygoscelis penguin species in the Antarctic Peninsula region. Mar Biol 164.

Hijmans RJ, Van Etten J, Cheng J, Mattiuzzi M, Sumner M, Greenberg JA (2015) Package 'raster'.

Hobbs WR, Massom R, Stammerjohn S, Reid P, Williams G, Meier W (2016) A review of recent changes in Southern Ocean sea ice, their drivers and forcings. Glob Planet Change 143: 228-250.

Hobson KA, Clark RG (1992) Assessing Avian Diets Using Stable Isotopes I: Turnover of ${ }^{13}$ $\mathrm{C}$ in Tissues. The Condor 94, 181-188.

Jackson AL, Inger R, Parnell AC, Bearhop S (2011) Comparing isotopic niche widths among and within communities: SIBER - Stable Isotope Bayesian Ellipses in R: Bayesian isotopic niche metrics. J Anim Ecol 80:595-602. 
Jenouvrier S, Holland M, Stroeve J, Barbraud C, Weimerskirch H, Serreze M, Caswell H (2012) Effects of climate change on an emperor penguin population: analysis of coupled demographic and climate models. Glob Change Biol 18(9):2756-2770.

Karnovsky N, Ainley DG, Lee P (2007) The Impact and Importance of Production in Polynyas to Top-Trophic Predators: Three Case Histories. Elsevier Oceanogr Ser 74:391-410.

Kato A, Ropert-Coudert Y, Naito Y (2009) Changes in Adélie penguin breeding populations in Lützow-Holm Bay, Antarctica, in relation to sea-ice conditions. Polar Biol 25(12):934-938.

Kirkwood R, Robertson G (1997) Seasonal change in the foraging ecology of emperor penguins on the Mawson Coast, Antarctica. Mar Ecol Prog Ser 156:205-223.

Knox GA (1994) Biology of the Southern Ocean. Cambridge University Press, Cambridge, UK and New York, NY, USA, 444 pp.

Koubbi P, Hosie G, Constable A, Raymond B, Moteki M, Améziane N, Causse R, Fuentes V, Heerah K, Penot F, Vincent D, Ancel A, Bost CA, Eléaume M, Lindsay D, Lindsay M, Cottin M, Charrassin JB, Ropert-Coudert Y, Toda R, Grossman M, Hopcroft R, OzoufCostaz C, Zimmer I, CEAMARC experts (2011a) Estimating the biodiversity of the shelf and oceanic zone of the d'Urville Sea (East Antarctica) for ecoregionalisation using the CEAMARC (Collaborative East Antarctic Marine Census) CAML surveys. Polar Sci 4:115-133.

Koubbi P, O’Brien C, Loots C, Giraldo C, Smith M, Tavernier E, Vacchi M, Vallet C, Chevallier J, Moteki M (2011b) Spatial distribution and inter-annual variations in the size frequency distribution and abundances of Pleuragramma antarcticum larvae in the Dumont d'Urville Sea from 2004 to 2010. Polar Sci 5(2):225-238. 
Labrousse S, Williams G, Tamura T, Bestley S, Sallée JB, Fraser AD, Sumner M, Roquet F, Heerah K, Picard B, Guinet C, Harcourt R, McMahon C, Hindell MA, Charrassin JB (2018) Coastal polynyas: Winter oases for subadult southern elephant seals in East Antarctica. Sci Rep 8(1):3183.

Le Guen C, Kato A, Raymond B, Barbraud C, Beaulieu M, Bost CA, Delord K, MacIntosh AJJ, Meyer X, Raclot T, Sumner M, Takahashi A, Thiebot JB, Ropert-Coudert Y (2018) Reproductive performance and diving behaviour share a common sea-ice concentration optimum in Adélie penguins (Pygoscelis adeliae). Glob Change Biol 24(11): 5304-5317.

Lenth R (2018) Emmeans: Estimated marginal means, aka least-squares means. R package version $1(1)$

Lynch HJ, LaRue MA (2014) First global census of the Adélie Penguin. The Auk 131(4):457-466.

McMahon C, Hindell M, Dorr T, Massom RA (2002) Winter distribution and abundance of crabeater seals off George V Land, East Antarctica. Antarct Sci 14:128-133.

Massom RA, Harris PT, Michael KJ, Potter MJ (1998) The distribution and formative processes of latent-heat polynyas in East Antarctica. Ann Glaciol 27:420-426.

Massom RA, Stammerjohn SE (2010) Antarctic sea ice change and variability - Physical and ecological implications. Polar Sci 4(2):149-186.

Massom R, Reid P, Stammerjohn S, Raymond B, Fraser A, Ushio S (2013) Change and Variability in East Antarctic Sea Ice Seasonality, 1979/80-2009/10. PLoS ONE 8, e64756.

Meyer B, Freier U, Grimm V, Groeneveld J, Hunt BPV, Kerwath S, King R, Klaas C, Pakhomov E, Meiners KM, Melbourne-Thomas J, Murphy EJ, Thorpe SE, Stammerjohn S, Wolf-Gladrow D, Auerswald L, Götz A, Halbach L, Jarman S, 
Kawaguchi S, Krumpen T, Nehrke G, Ricker R, Sumner M, Teschke M, Trebilco R, Yilmaz NI (2017) The winter pack-ice zone provides a sheltered but food-poor habitat for larval Antarctic krill. Nat Ecol Evol 1(12): 1853-1861.

Nesti I, Ropert-Coudert Y, Kato A, Beaulieu M, Focardi S, Olmastroni S (2010) Diving behaviour of chick-rearing Adélie Penguins at Edmonson Point, Ross Sea. Polar Biol 33(7): 969-978.

Nicol S, Pauly T, Bindoff NL, Wright S, Thiele D, Hosie,GW, ... \& Woehler E (2000). Ocean circulation off east Antarctica affects ecosystem structure and sea-ice extent. Nature 406(6795): 504-507.

Pacoureau N, Authier M, Delord K, Barbraud C (2019) Population response of an apex Antarctic consumer to its prey and climate fluctuations. Oecologia 189(2):279-291.

Peron C, Weimerskirch H, Bost CA (2012) Projected poleward shift of king penguins' (Aptenodytes patagonicus) foraging range at the Crozet Islands, southern Indian Ocean. Proc R Soc B Biol Sci 279(1738): 2515-2523.

Post DM (2002) Using stable isotopes to estimate trophic position: models, methods, and assumptions. Ecology 83(3): 703-718.

R Core Team (2017) R: a language and environment for statistical computing. R Foundation for Statistical Computing, Vienna

Ropert-Coudert Y, Kato A, Baudat J, Bost CA, Le Maho Y, Naito Y (2001a) Feeding strategies of free-ranging Adélie penguins Pygoscelis adeliae analysed by multiple data recording. Polar Biol 24(6): 460-466.

Ropert-Coudert Y, Kato A, Baudat J, Bost CA, Le Maho Y, Naito Y (2001b) Time/depth usage of Adélie penguins: an approach based on dive angles. Polar Biol 24(6): 467-470. 
Ropert-Coudert Y, Kato A, Bost CA, Rodary D, Sato K, LeMaho Y, Naito Y (2002a) Do Adélie penguins modify their foraging behaviour in pursuit of different prey? Mar Biol 140(3): 647-652.

Ropert-Coudert Y, Kato A, Sato K, Naito Y (2002b) Swim speed of free-ranging Adélie penguins and its relation to the maximum depth of dives. J Avian Biol 33(1): 94:99.

Ropert-Coudert Y, Grémillet D, Kato A, Ryan PG, Naito Y, Le Maho Y (2004) A fine-scale time budget of Cape gannets provides insights into the foraging strategies of coastal seabirds. Anim Behav 67(5): 985-992.

Ropert-Coudert Y, Kato A, Shiomi K, Barbraud C, Angelier F, Delord K, Poupart T, Koubbi P, Raclot T (2018) Two Recent Massive Breeding Failures in an Adélie Penguin Colony Call for the Creation of a Marine Protected Area in D’Urville Sea/Mertz. Front Mar Sci 5: 264.

Smetacek V, Assmy P, Henjes J (2004) The role of grazing in structuring Southern Ocean pelagic ecosystems and biogeochemical cycles. Antarct Sci 16: 541-558.

Smith WO, Barber DG (2007) Chapter 13 - Polynyas and Climate Change: A View to the Future. Elsevier Oceanogr Ser 74: 411-419.

Southwell C, Emmerson L, Takahashi A, Barbraud C, Delord K, Weimerskirch H (2017) Large-scale population assessment informs conservation management for seabirds in Antarctica and the Southern Ocean: a case study of Adélie penguins. Glob Ecol Conserv 9: $104-115$.

Stammerjohn SE, Smith RC (1997) Opposing Southern Ocean climate patterns as revealed by trends in regional sea ice coverage. Climatic Change 37(4): 617-639.

Traisnel G, Pichegru L (2019) Success comes with consistency in hard times: foraging repeatability relates to sex and breeding output in African penguins. Mar Ecol Prog Ser 608: 279-289. 
Warwick-Evans V, Atkinson P, Gauvain R, Robinson L, Arnould J, Green J (2015) Time-inarea represents foraging activity in a wide-ranging pelagic forager. Mar Ecol Prog Ser 527: $233-246$.

Watanuki Y, Kato A, Naito Y, Robertson G, Robinson S (1997) Diving and foraging behaviour of Adélie penguins in areas with and without fast sea-ice. Polar Biol 17(4):296-304.

Watanuki Y, Kato A, Sato K, Niizuma Y, Bost CA, Maho YL, Naito Y (2002) Parental mass change and food provisioning in Adélie penguins rearing chicks in colonies with contrasting sea-ice conditions. Polar Biol 25(9):672:681.

Weimerskirch H, Pinaud D, Pawlowski F, Bost C (2007) Does Prey Capture Induce Area-Restricted Search? A Fine-Scale Study Using GPS in a Marine Predator, the Wandering Albatross. Am Nat 170(5):734-743.

Weimerskirch H, Bertrand S, Silva J, Marques JC, Goya E (2010) Use of Social Information in Seabirds: Compass Rafts Indicate the Heading of Food Patches. PLoS ONE 5(3):e9928.

Widmann M, Kato A, Raymond B, Angelier F, Arthur B, Chastel O, Pellé M, Raclot T, Ropert-Coudert Y (2015) Habitat use and sex-specific foraging behaviour of Adélie penguins throughout the breeding season in Adélie Land, East Antarctica. Mov Ecol $3(1): 30$.

Wienecke BC, Lawless R, Rodary D, Thomson R, Pauly T, Robertson G, Kerry KR, LeMaho Y (2000) Adélie penguin foraging behaviour and krill abundance along the Wilkes and Adélie land coasts, Antarctica. Deep Sea Res Part 2 Top Stud Oceanogr 47(12-13):25732587. 
Wilson KJ, Turney CSM, Fogwill CJ, Blair E (2016) The impact of the giant iceberg B09B on population size and breeding success of Adélie penguins in Commonwealth Bay, Antarctica. Antarct Sci 28(3):187-193.

Wilson PR, Piitz K, Peters G, Culik B, Scolaro JA, Charrassin JB, Ropert-Coudert Y (1997) Long-term attachment of transmitting and recording devices to penguins and other seabirds. Wildl Soc Bull 25(1):101-106.

Xavier JC, Trathan PN, Ceia FR, Tarling GA, Adlard S, Fox D, Edwards EWJ, Vieira RP, Medeiros R, De Broyer C, Cherel Y (2017) Sexual and individual foraging segregation in Gentoo penguins Pygoscelis papua from the Southern Ocean during an abnormal winter. PLOS ONE 12(3):e0174850. 
Table 1. Number of Adélie penguin GPS tracks analysed, mean trip duration, total trip distance and maximum distance to colony for females from the Ile des Pétrels colony in 2016 and males from the Cap Bienvenue colony in 2017, and result of the Student's $t$-tests comparing trip parameters between colonies.

\begin{tabular}{|cccccccc|}
\hline \multirow{2}{*}{ Sex: year } & \multirow{2}{*}{ Colony } & \multirow{2}{*}{ Trips } & \multicolumn{2}{c}{ Trip duration $(\mathrm{d})$} & \multicolumn{2}{c|}{ Total distance $(\mathrm{km})$} & \multicolumn{2}{c|}{ Maximum distance $(\mathrm{km})$} \\
\cline { 4 - 8 } & & Mean \pm SD & p-value & Mean \pm SD & p-value & Mean \pm SD & p-value \\
\hline \multirow{2}{*}{ Females: 2016} & Ile des Pétrels & 10 & $21.28 \pm 4.90$ & 0.260 & $779.18 \pm 148.78$ & 0.747 & $237.07 \pm 35.53$ \\
& Cap Bienvenue & 10 & $19.00 \pm 3.78$ & & $748.20 \pm 170.70$ & 0.936 & $235.57 \pm 46.38$ \\
Males: 2017 & Ile des Pétrels & 10 & $17.06 \pm 2.22$ & 0.268 & $751.72 \pm 91.76$ & 0.285 & $270.92 \pm 37.53$ \\
& Cap Bienvenue & 14 & $16.01 \pm 2.25$ & & $810.00 \pm 168.00$ & 0.099 \\
\end{tabular}


Table 2. Pairwise comparison of open water feature effects on residence time of Adélie penguin females from each colony in 2016, with the estimates, standard error (SE) and p-value corresponding to the significance of the effect of one feature on the other. Significant differences between open water feature effects are indicated as * $p<0.05$; * $\mathrm{p}<0.01$; *** $<0.001$. Each reference open water feature is compared to the other levels. CB polynya: Commonwealth Bay polynya.

\begin{tabular}{|c|c|c|c|c|c|c|c|}
\hline \multirow{2}{*}{$\begin{array}{l}\text { Reference } \\
\text { feature }\end{array}$} & \multirow{2}{*}{$\begin{array}{l}\text { Compared } \\
\text { feature }\end{array}$} & \multicolumn{3}{|c|}{ Ile des Pétrels } & \multicolumn{3}{|c|}{ Cap Bienvenue } \\
\hline & & Estimate & $\mathrm{SE}$ & p-value & Estimate & SE & p-value \\
\hline \multirow[t]{4}{*}{ Ice edge } & Open sea & 0.166 & 0.124 & 0.943 & -0.158 & 0.105 & 0.888 \\
\hline & Sea ice & 0.065 & 0.054 & 0.972 & 0.194 & 0.054 & $0.012 *$ \\
\hline & Flaw leads & 0.052 & 0.074 & 0.999 & 0.356 & 0.084 & $0.001 * * *$ \\
\hline & $\mathrm{CB}$ polynya & 0.496 & 0.101 & $<0.001 * * *$ & 0.835 & 0.100 & $<0.001 * * *$ \\
\hline \multirow[t]{3}{*}{ Open sea } & Sea ice & -0.102 & 0.121 & 0.998 & 0.353 & 0.102 & 0.020* \\
\hline & Flaw leads & -0.114 & 0.131 & 0.997 & 0.514 & 0.121 & $<0.001 * * *$ \\
\hline & CB polynya & 0.330 & 0.146 & 0.416 & 0.993 & 0.129 & $<0.001 * * *$ \\
\hline \multirow[t]{2}{*}{ Sea ice } & Flaw leads & -0.012 & 0.0363 & 1.000 & 0.161 & 0.075 & 0.497 \\
\hline & CB polynya & 0.431 & 0.096 & $<0.001 * * *$ & 0.640 & 0.096 & $<0.001 * * *$ \\
\hline Flaw leads & CB polynya & 0.167 & 0.145 & 0.979 & 0.479 & 0.116 & $0.001 * *$ \\
\hline
\end{tabular}


Table 3. Pairwise comparison of bathymetric feature effects on residence time of Adélie penguin females from each colony in 2016 , with the estimates, standard error (SE) and p-value corresponding to the significance of the effect of one feature on the other. Significant differences between bathymetric feature effects are indicated as $* \mathrm{p}<0.05 ; * * \mathrm{p}<0.01 ; * * \mathrm{p}<0.001$. Each reference bathymetric feature is compared to the other levels.

\begin{tabular}{|c|c|c|c|c|c|c|c|}
\hline \multirow{2}{*}{$\begin{array}{l}\text { Reference } \\
\text { feature }\end{array}$} & \multirow{2}{*}{$\begin{array}{l}\text { Compared } \\
\text { feature }\end{array}$} & \multicolumn{3}{|c|}{ Ile des Pétrels } & \multicolumn{3}{|c|}{ Cap Bienvenue } \\
\hline & & Estimate & $\mathrm{SE}$ & $\mathrm{p}$-value & Estimate & $\mathrm{SE}$ & p-value \\
\hline Continental shelf & $\begin{array}{l}\text { Slope } 550-2000 \mathrm{~m} \\
\text { Slope } 2000-2500 \mathrm{~m} \\
\text { Slope } 2500-3000 \mathrm{~m} \\
\text { Abyssal plain }\end{array}$ & $\begin{array}{l}-0.164 \\
-0.286 \\
-0.437 \\
-0.684\end{array}$ & $\begin{array}{l}0.058 \\
0.048 \\
0.059 \\
0.208\end{array}$ & $\begin{array}{c}0.134 \\
<0.001 * * * \\
<0.001 * * * \\
\mathbf{0 . 0 3 4} *\end{array}$ & $\begin{array}{l}-0.088 \\
-0.526 \\
-0.737 \\
-1.104\end{array}$ & $\begin{array}{l}0.061 \\
0.050 \\
0.065 \\
0.140\end{array}$ & $\begin{aligned} & 0.912 \\
< & \mathbf{0 . 0 0 1} * * * * \\
< & <0.001 * * * \\
< & <0.001 * * *\end{aligned}$ \\
\hline Slope $550-2000 \mathrm{~m}$ & $\begin{array}{l}\text { Slope } 2000-2500 \mathrm{~m} \\
\text { Slope } 2500-3000 \mathrm{~m} \\
\text { Abyssal plain }\end{array}$ & $\begin{array}{l}-0.122 \\
-0.273 \\
-0.520\end{array}$ & $\begin{array}{l}0.057 \\
0.069 \\
0.211\end{array}$ & $\begin{array}{c}0.504 \\
\mathbf{0 . 0 0 3} * \\
0.288\end{array}$ & $\begin{array}{l}-0.438 \\
-0.646 \\
-1.016\end{array}$ & $\begin{array}{l}0.060 \\
0.074 \\
0.144\end{array}$ & $\begin{array}{l}<0.001 * * * \\
<0.001 * * * * \\
<0.001 * * *\end{array}$ \\
\hline Slope $2000-2500 \mathrm{~m}$ & $\begin{array}{l}\text { Slope } 2500-3000 \mathrm{~m} \\
\text { Abyssal plain }\end{array}$ & $\begin{array}{l}-0.150 \\
-0.398\end{array}$ & $\begin{array}{l}0.060 \\
0.208\end{array}$ & $\begin{array}{l}0.270 \\
0.662\end{array}$ & $\begin{array}{l}-0.2074 \\
-0.578\end{array}$ & $\begin{array}{l}0.066 \\
0.141\end{array}$ & $\begin{array}{c}0.053 \\
\mathbf{0 . 0 0 2} * *\end{array}$ \\
\hline Slope $2500-3000 \mathrm{~m}$ & Abyssal plain & -0.248 & 0.209 & 0.975 & -0.370 & 0.143 & 0.224 \\
\hline
\end{tabular}


Table 4. Pairwise comparison of open water feature effects on residence time of Adélie penguin males from each colony in 2017, with the estimates, standard error (SE) and p-value corresponding to the significance of the effect of one feature on the other. Significant differences between open water feature effects are indicated as $* \mathrm{p}<0.05 ; * \mathrm{p}<0.01$; ***p $<0.001$. (-) indicates features were not visited so values of residence time were not calculated. Each reference open water feature is compared to the other levels. CB: Commonwealth Bay polynya; DDU:

Dumont d'Urville polynya.

\begin{tabular}{|c|c|c|c|c|c|c|c|}
\hline \multirow{2}{*}{$\begin{array}{l}\text { Reference } \\
\text { feature }\end{array}$} & \multirow{2}{*}{$\begin{array}{l}\text { Compared } \\
\text { feature }\end{array}$} & \multicolumn{3}{|c|}{ Ile des Pétrels } & \multicolumn{3}{|c|}{ Cap Bienvenue } \\
\hline & & Estimate & SE & p-value & Estimate & SE & p-value \\
\hline \multirow[t]{4}{*}{ Ice edge } & Open sea & 0.324 & 0.059 & $<0.001 * * * *$ & 0.046 & 0.047 & 0.998 \\
\hline & Sea ice & -0.043 & 0.049 & 0.999 & 0.246 & 0.043 & $<0.001 * * *$ \\
\hline & DDU polynya & 0.586 & 0.083 & $<0.001 * * *$ & 0.514 & 0.093 & $<0.001 * * *$ \\
\hline & $\mathrm{CB}$ polynya & 0.461 & 0.350 & 0.977 & 1.004 & 0.313 & 0.059 \\
\hline \multirow[t]{2}{*}{ Open sea } & Sea ice & -0.367 & 0.060 & $<0.001 * * *$ & 0.200 & 0.044 & $0.003 * * *$ \\
\hline & $\mathrm{CB}$ polynya & 0.137 & 0.351 & 1.000 & 0.958 & 0.313 & 0.091 \\
\hline \multirow[t]{3}{*}{ Sea ice } & Flaw leads & -0.258 & 0.537 & 1.000 & - & - & - \\
\hline & DDU polynya & 0.629 & 0.083 & $<0.001 * * *$ & 0.267 & 0.092 & 0.139 \\
\hline & $\mathrm{CB}$ polynya & 0.504 & 0.350 & 0.955 & 0.758 & 0.312 & 0.388 \\
\hline \multirow[t]{2}{*}{ Flaw leads } & DDU polynya & 0.887 & 0.541 & 0.894 & - & - & - \\
\hline & $\mathrm{CB}$ polynya & 0.762 & 0.638 & 0.990 & - & - & - \\
\hline
\end{tabular}


Table 5. Pairwise comparison of bathymetric feature effects on residence time of Adélie penguin males from each colony in 2017, with the estimates, standard error (SE) and p-value corresponding to the significance of the effect of one feature on the other. Significant differences between bathymetric features effects are indicated as * $p<0.05 ; *$ p $<0.01$; ***p $<0.001$. Each reference bathymetric feature is compared to the other levels.

\begin{tabular}{|c|c|c|c|c|c|c|c|}
\hline \multirow{2}{*}{$\begin{array}{l}\text { Reference } \\
\text { feature }\end{array}$} & \multirow{2}{*}{$\begin{array}{l}\text { Compared } \\
\text { feature }\end{array}$} & \multicolumn{3}{|c|}{ Ile des Pétrels } & \multicolumn{3}{|c|}{ Cap Bienvenue } \\
\hline & & Estimate & SE & $\mathrm{p}$-value & Estimate & SE & p-value \\
\hline Continental shelf & $\begin{array}{l}\text { Slope } 550-2000 \mathrm{~m} \\
\text { Slope } 2000-2500 \mathrm{~m} \\
\text { Slope } 2500-3000 \mathrm{~m} \\
\text { Abyssal plain }\end{array}$ & $\begin{array}{l}-0.058 \\
-0.365 \\
-0.776 \\
-0.700\end{array}$ & $\begin{array}{l}0.064 \\
0.058 \\
0.056 \\
0.079\end{array}$ & $\begin{array}{c}0.996 \\
<\mathbf{0 . 0 0 1} * * * \\
<\mathbf{0 . 0 0 1} * * * \\
<\mathbf{0 . 0 0 1} * * *\end{array}$ & $\begin{array}{l}-0.180 \\
-0.365 \\
-0.863 \\
-0.641\end{array}$ & $\begin{array}{l}0.048 \\
0.044 \\
0.052 \\
0.119\end{array}$ & $\begin{array}{l}0.007 * * \\
<0.001 * * * \\
<0.001 * * * \\
<0.001 * * *\end{array}$ \\
\hline Slope $550-2000 \mathrm{~m}$ & $\begin{array}{l}\text { Slope } 2000-2500 \mathrm{~m} \\
\text { Slope } 2500-3000 \mathrm{~m} \\
\text { Abyssal plain }\end{array}$ & $\begin{array}{l}-0.307 \\
-0.717 \\
-0.642\end{array}$ & $\begin{array}{l}0.067 \\
0.068 \\
0.090\end{array}$ & $\begin{array}{l}<0.001 * * * \\
<0.001 * * * \\
<0.001 * * *\end{array}$ & $\begin{array}{l}-0.185 \\
-0.682 \\
-0.460\end{array}$ & $\begin{array}{l}0.053 \\
0.060 \\
0.123\end{array}$ & $\begin{array}{c}\mathbf{0 . 0 1 7} * \\
<0.001 * * * \\
0.007 * *\end{array}$ \\
\hline Slope $2000-2500 \mathrm{~m}$ & $\begin{array}{l}\text { Slope } 2500-3000 \mathrm{~m} \\
\text { Abyssal plain }\end{array}$ & $\begin{array}{l}-0.410 \\
-0.334\end{array}$ & $\begin{array}{l}0.061 \\
0.084\end{array}$ & $\begin{array}{c}<0.001 * * * \\
0.003 * *\end{array}$ & $\begin{array}{l}-0.498 \\
-0.276\end{array}$ & $\begin{array}{l}0.056 \\
0.121\end{array}$ & $\begin{array}{c}<0.001 * * * \\
0.407\end{array}$ \\
\hline Slope $2500-3000 \mathrm{~m}$ & Abyssal plain & 0.076 & 0.082 & 0.996 & 0.222 & 0.123 & 0.732 \\
\hline
\end{tabular}




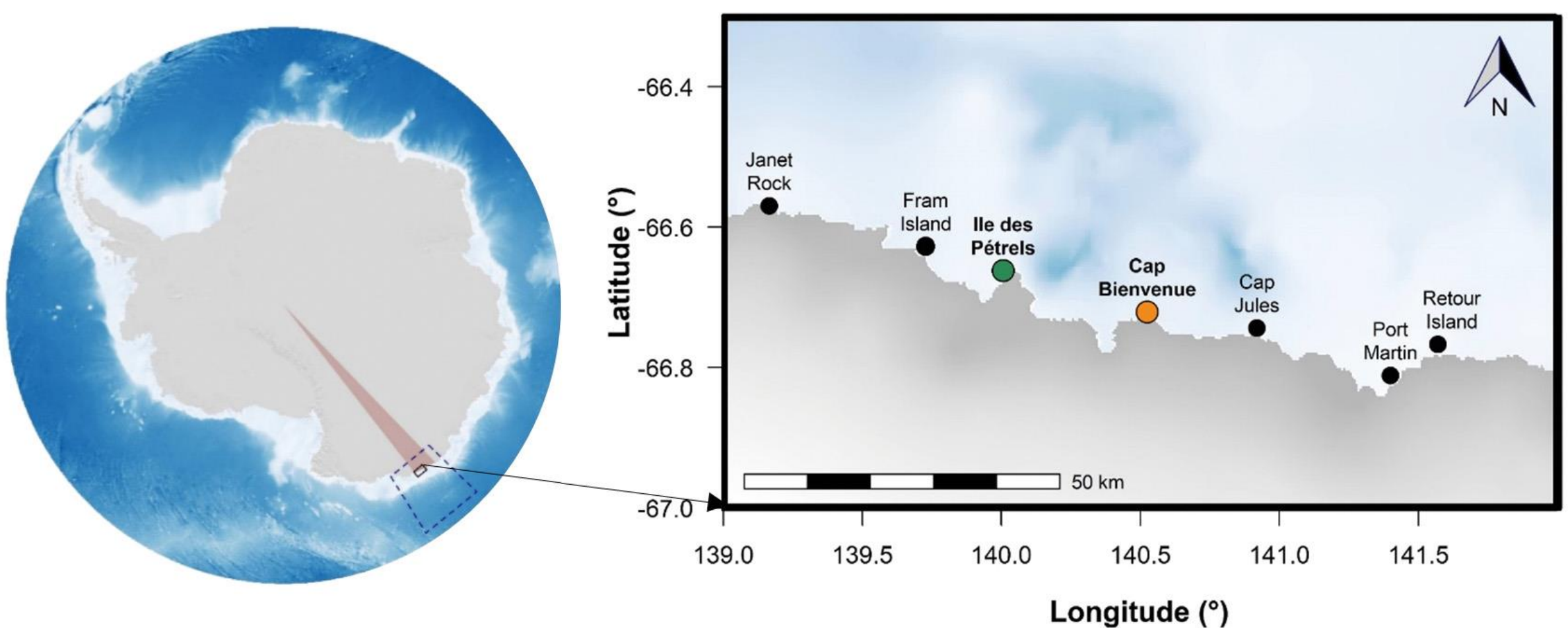

Figure 1. Global view of Antarctica (left) with the Terre Adélie sector (red triangle) and a close-up (right) of the coastline in Terre Adélie (black polygon) within our study area (larger dashed-blue polygon), showing the 2 studied Adélie penguin colonies: Ile des Pétrels in green, and Cap Bienvenue in orange. Note that the colony colour-code is used in all figures. Other surrounding colonies are indicated with black dots. 


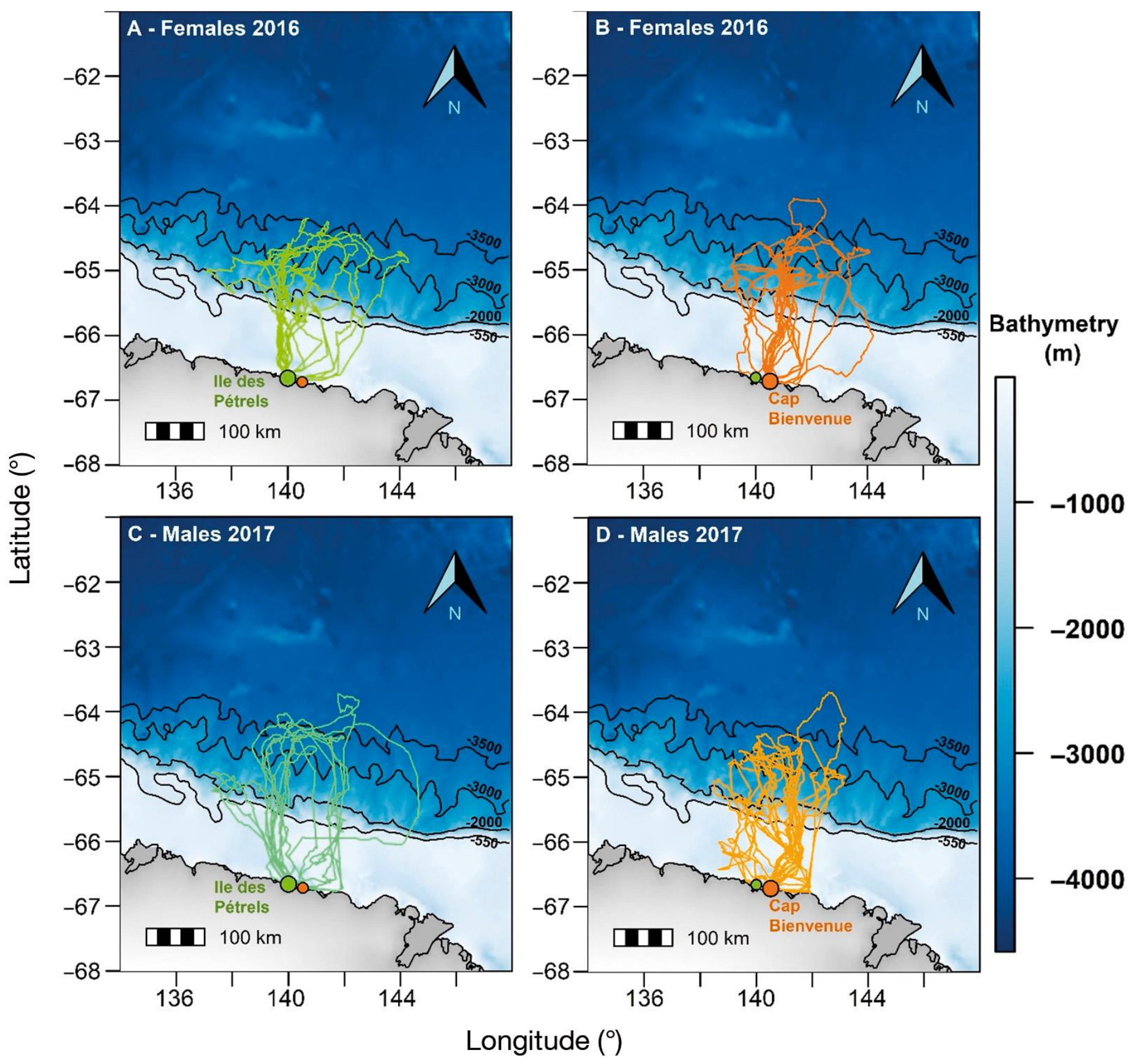

Figure 2. GPS-tagged Adélie penguin tracks, showing female movements in 2016 from (A) Ile des Pétrels and (B) Cap Bienvenue, and male movements in 2017 from (C) Ile des Pétrels and (D) Cap Bienvenue (see Fig. 1 for colony locations). Black lines: bathymetric limit of the continental shelf and slope. 

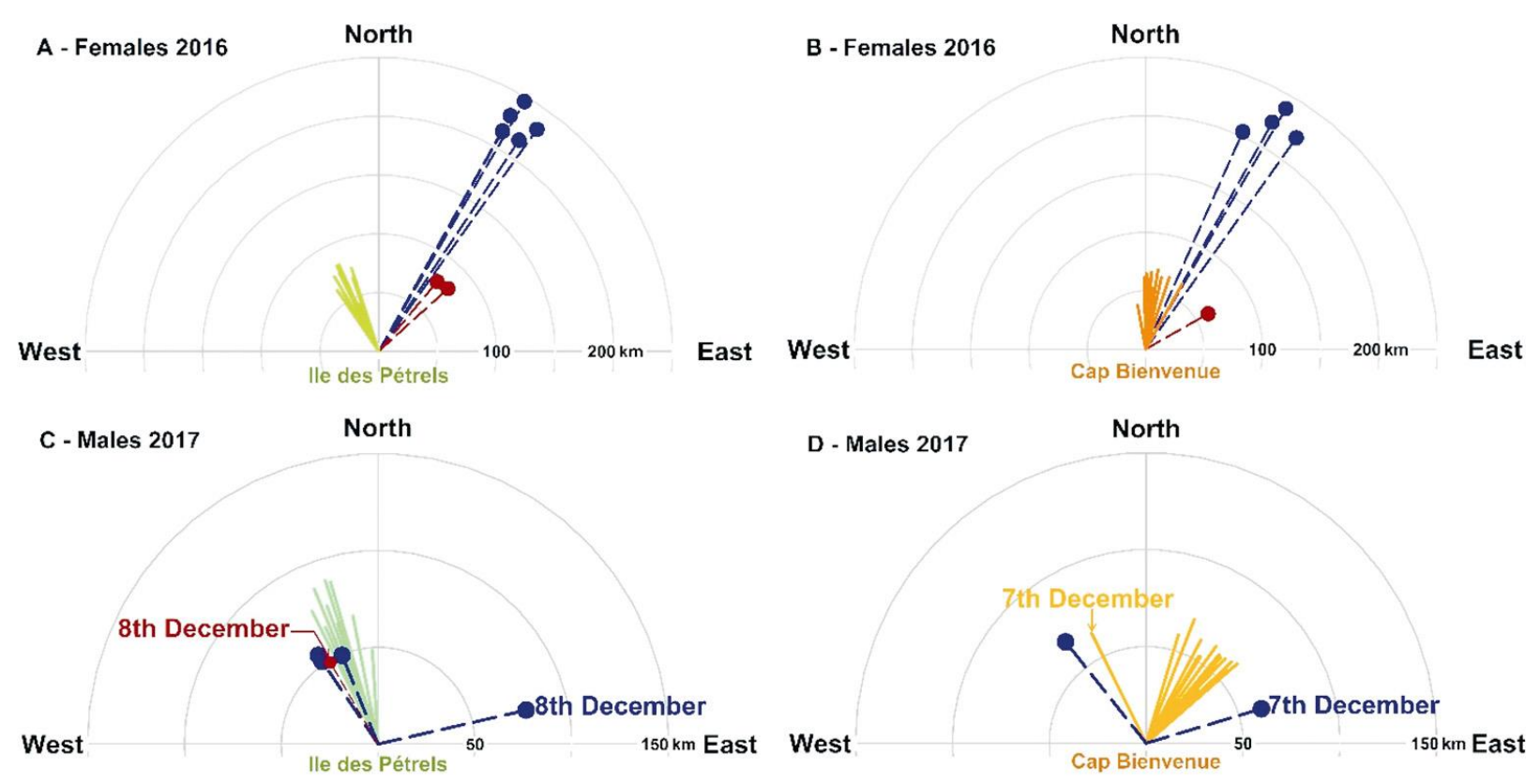

Fig. 3. Directions and distance taken by Adélie penguins (solid lines) from (A,C) the Ile des Pétrels, and (B,D) Cap Bienvenue after a $24 \mathrm{~h}$ trip (females and males departed their colonies between 20-28 Nov 2016 and 4-8 Dec 2017 respectively), together with the direction of the closest ice edge (dotted navy lines) and, when opened and closer to the colonies, the closest polynya or leads (dotted brown lines) from each colony on the day of the birds' departure. Note that in $(\mathrm{C})$, the ice edge moved east of the Iles des Pétrels colony on 8 December and a polynya opened (indicated in red). Note that in (D), the ice edge moved on 7 December, and one male from Cap Bienvenue took the opposite direction. 

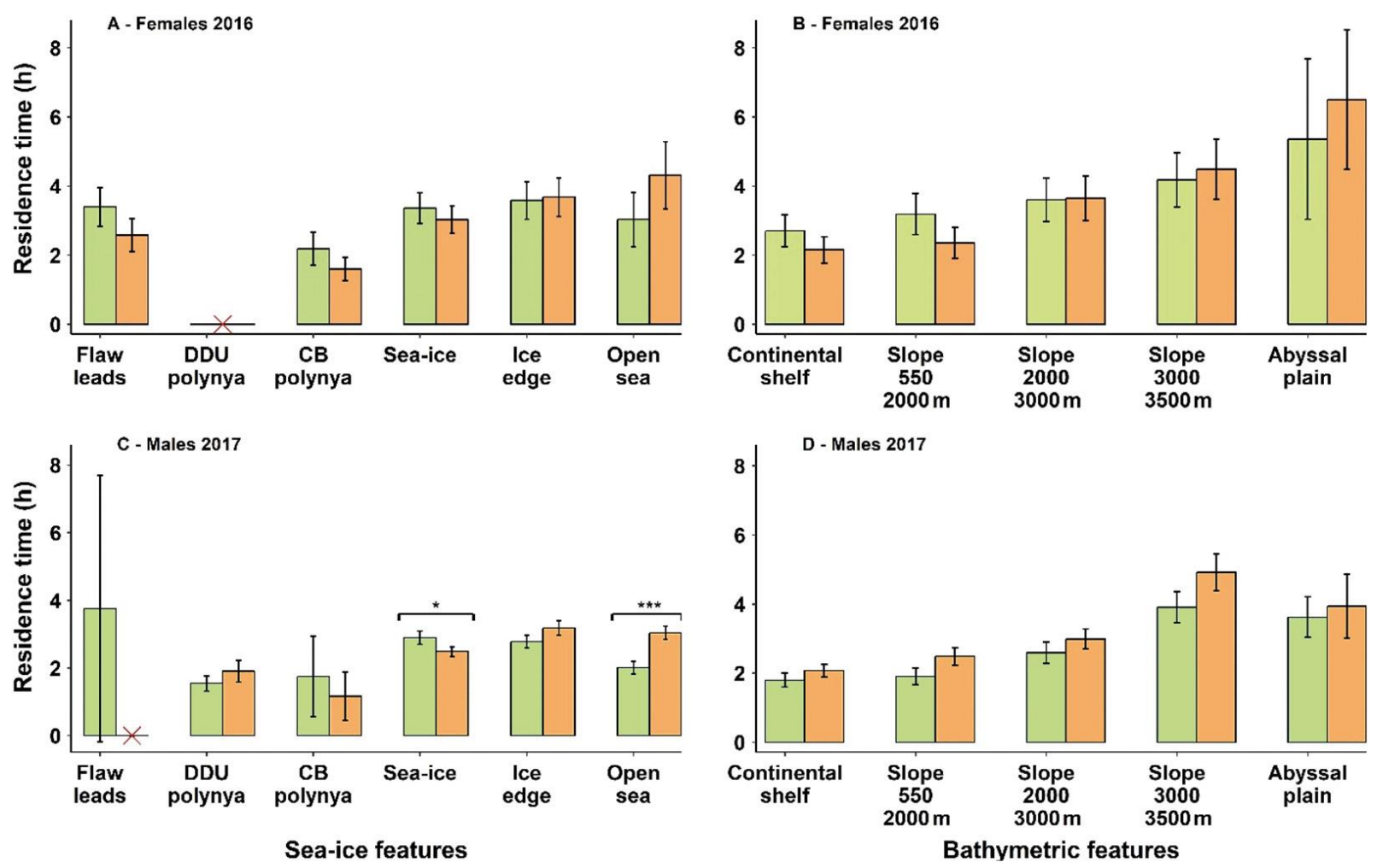

Figure 4. Average $( \pm C I)$ residence time in each $(A, C)$ open water feature and $(B, D)$ topographic feature for Adélie penguin (A,B) females and (C,D) males from the Ile des Pétrels colony (green bars) and Cap Bienvenue colony (orange bars). DDU: Dumont d'Urville polynya; CB Commonwealth Bay polynya. Significant differences between colonies are indicated as $* \mathrm{p}<0.05 ; * * * \mathrm{p}<0.001$. Red crosses: residence time was not calculated for the specific feature (feature not present or not visited by penguins). Differences between each feature within colony are not indicated on the figure for clarity reasons but results can be found in Tables 2-4. 

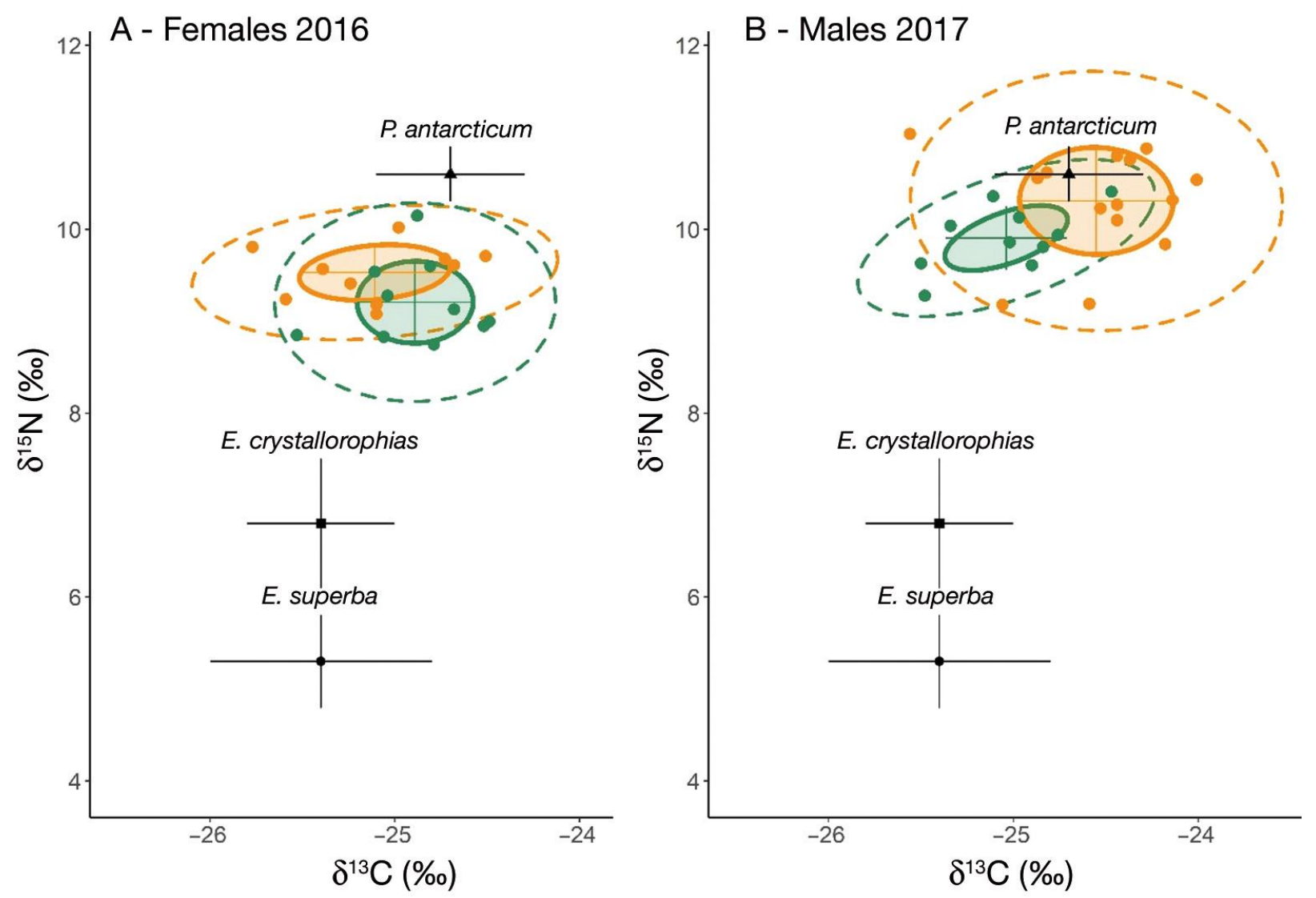

Figure 5. Mean $( \pm \mathrm{SD})$ carbon $\left(\delta^{13} \mathrm{C}\right)$ and nitrogen $\left(\delta^{15} \mathrm{~N}\right)$ isotopic ratios for Adélie penguin (A) females and (B) males from the Ile des Pétrels (green) and Cap Bienvenue (orange) colonies, and representation of the $40 \%$ standard ellipse area corrected for small sample size (solid line) and 95\% Bayesian standard ellipses areas (dashed line) for each colony. Individual values are given as small circles with the same colour code (see also Table A1). Mean Adélie penguin prey isotopic ratios $( \pm$ SD) are indicated in black, following Cherel (2008). 


\section{Supplementary material}

Table S1. Carbon $\left(\delta^{13} \mathrm{C}\right)$, nitrogen $\left(\delta^{15} \mathrm{~N}\right)$ and carbon:nitrogen $(\mathrm{C} / \mathrm{N})$ isotopic ratios for Adélie penguin females (2016-2017) and males (2017-2018) in both colonies. No significant difference was detected between colonies for their $\delta^{15} \mathrm{~N}$ values within each year (females: $9.5 \pm$ 0.3 and $9.21 \pm 0.4 \%$ for Cap Bienvenue and Ile des Pétrels respectively, $\mathrm{p}>0.05$; males: 10.3 \pm 0.6 and $9.91 \pm 0.4 \%$ or Cap Bienvenue and Ile des Pétrels respectively, $\mathrm{p}>0.05)$. No difference was detected for females $\delta^{13} \mathrm{C}$ values between the 2 colonies $(25.1 \pm 0.4$ and $-24.9 \pm$ $0.3 \%$ for Cap Bienvenue and the Ile des Pétrels), but the $\delta^{13} \mathrm{C}$ values were significantly higher for males from Cap Bienvenue than for those from the Ile des Pétrels in $2017(-24.5 \pm 0.4$ and $-25.0 \pm 0.3$ respectively, $\mathrm{p}=0.005)$.

\begin{tabular}{|cccccc|}
\hline Year & Individual & Colony & $\delta^{13} \mathrm{C}$ & $\delta^{15} \mathrm{~N}$ & $\mathrm{C} / \mathrm{N}$ \\
\hline $2016-2017$ & CB1 & Cap Bienvenue & -24.68 & 9.61 & 3.34 \\
$2016-2017$ & CB2 & Cap Bienvenue & -24.98 & 10.02 & 3.31 \\
$2016-2017$ & CB4 & Cap Bienvenue & -24.51 & 9.71 & 3.34 \\
$2016-2017$ & CB5 & Cap Bienvenue & -25.39 & 9.57 & 3.45 \\
$2016-2017$ & CB6 & Cap Bienvenue & -24.73 & 9.68 & 3.41 \\
$2016-2017$ & CB9 & Cap Bienvenue & -25.59 & 9.24 & 3.52 \\
$2016-2017$ & CB10 & Cap Bienvenue & -25.10 & 9.18 & 3.42 \\
$2016-2017$ & CB11 & Cap Bienvenue & -25.77 & 9.81 & 3.37 \\
$2016-2017$ & CB13 & Cap Bienvenue & -25.10 & 9.08 & 3.36 \\
$2016-2017$ & CB14 & Cap Bienvenue & -25.24 & 9.41 & 3.46 \\
$2016-2017$ & A1 & Ile des Pétrels & -24.81 & 9.60 & 3.31 \\
$2016-2017$ & A5 & Ile des Pétrels & -25.04 & 9.28 & 3.33 \\
$2016-2017$ & A6 & Ile des Pétrels & -25.06 & 8.83 & 3.39 \\
$2016-2017$ & A7 & Ile des Pétrels & -25.11 & 9.54 & 3.30 \\
$2016-2017$ & A8 & Ile des Pétrels & -24.79 & 8.75 & 3.31 \\
$2016-2017$ & A10 & Ile des Pétrels & -24.49 & 9.00 & 3.33 \\
$2016-2017$ & A11 & Ile des Pétrels & -24.52 & 8.95 & 3.35 \\
$2016-2017$ & A12 & Ile des Pétrels & -24.68 & 9.13 & 3.36 \\
$2016-2017$ & A14 & Ile des Pétrels & -24.88 & 10.15 & 3.32 \\
$2016-2017$ & A15 & Ile des Pétrels & -25.53 & 8.85 & 3.36 \\
$2017-2018$ & CB1 & Cap Bienvenue & -24.44 & 10.10 & 3.33 \\
$2017-2018$ & CB2 & Cap Bienvenue & -24.82 & 10.62 & 3.31 \\
$2017-2018$ & CB3 & Cap Bienvenue & -24.37 & 10.76 & 3.39 \\
$2017-2018$ & CB4 & Cap Bienvenue & -25.56 & 11.04 & 3.38 \\
$2017-2018$ & CB5 & Cap Bienvenue & -24.53 & 10.23 & 3.38 \\
$2017-2018$ & CB6 & Cap Bienvenue & -24.01 & 10.54 & 3.30 \\
$2017-2018$ & CB8 & Cap Bienvenue & -25.06 & 9.18 & 3.29 \\
$2017-2018$ & CB9 & Cap Bienvenue & -24.44 & 10.27 & 3.39 \\
$2017-2018$ & CB10 & Cap Bienvenue & -24.28 & 10.88 & 3.30 \\
$2017-2018$ & CB11 & Cap Bienvenue & -24.44 & 10.80 & 3.33 \\
$2017-2018$ & CB12 & Cap Bienvenue & -24.87 & 10.56 & 3.33 \\
$2017-2018$ & CB13 & Cap Bienvenue & -24.59 & 9.19 & 3.31 \\
\hline
\end{tabular}




\begin{tabular}{|lclccc|}
\hline $2017-2018$ & CB14 & Cap Bienvenue & -24.14 & 10.32 & 3.32 \\
$2017-2018$ & CB15 & Cap Bienvenue & -24.18 & 9.84 & 3.30 \\
$2017-2018$ & B1 & Ile des Pétrels & -24.84 & 9.81 & 3.29 \\
$2017-2018$ & B3 & Ile des Pétrels & -25.50 & 9.63 & 3.31 \\
$2017-2018$ & B5 & Ile des Pétrels & -24.97 & 10.13 & 3.34 \\
$2017-2018$ & B7 & Ile des Pétrels & -25.48 & 9.28 & 3.29 \\
$2017-2018$ & B8 & Ile des Pétrels & -25.34 & 10.04 & 3.36 \\
$2017-2018$ & B11 & Ile des Pétrels & -24.90 & 9.61 & 3.33 \\
$2017-2018$ & B12 & Ile des Pétrels & -25.11 & 10.36 & 3.30 \\
$2017-2018$ & B13 & Ile des Pétrels & -24.47 & 10.41 & 3.34 \\
$2017-2018$ & B17 & Ile des Pétrels & -25.02 & 9.86 & 3.32 \\
$2017-2018$ & B20 & Ile des Pétrels & -24.76 & 9.94 & 3.30 \\
\hline
\end{tabular}

